\title{
Article
}

\section{HIV-1 Tat Protein Enters Dysfunctional Endothelial Cells via Integrins and Renders Them Permissive to Virus Replication}

\author{
Aurelio Cafaro ${ }^{1,+}{ }^{\oplus}$, Giovanni Barillari ${ }^{2,+}{ }^{+}$, Sonia Moretti ${ }^{1}$, Clelia Palladino ${ }^{1} \oplus$, Antonella Tripiciano ${ }^{1}$, \\ Mario Falchi ${ }^{1}$, Orietta Picconi ${ }^{1}$, , Maria Rosaria Pavone Cossut ${ }^{1}$, Massimo Campagna ${ }^{1}$, Angela Arancio ${ }^{1}$, \\ Cecilia Sgadari ${ }^{1} \mathbb{D}$, Claudia Andreini ${ }^{3}$, Lucia Banci ${ }^{3}$, Paolo Monini ${ }^{1}$ and Barbara Ensoli ${ }^{1, * \mathbb{D}}$
}

1 National HIV/AIDS Research Center, Istituto Superiore di Sanità, V.le Regina Elena 299, 00161 Rome, Italy; aurelio.cafaro@iss.it (A.C.); sonia.moretti@iss.it (S.M.); clelia.palladino@iss.it (C.P.); antonella.tripiciano@iss.it (A.T.); mario.falchi@iss.it (M.F.); orietta.picconi@iss.it (O.P.); mariarosaria.pavonecossut@iss.it (M.R.P.C.); massimo.campagna@iss.it (M.C.); angela.arancio@iss.it (A.A.); cecilia.sgadari@iss.it (C.S.); paolo.monini@iss.it (P.M.)

2 Department of Clinical Sciences and Translational Medicine, University “Tor Vergata", 00161 Rome, Italy; barillar@uniroma2.it

3 CERM (Magnetic Resonance Center), University of Florence, 50019 Florence, Italy; andreini@cerm.unifi.it (C.A.); banci@cerm.unifi.it (L.B.)

* Correspondence: barbara.ensoli@iss.it

+ These authors contributed equally to this work.

Citation: Cafaro, A.; Barillari, G.; Moretti, S.; Palladino, C.; Tripiciano, A.; Falchi, M.; Picconi, O.; Pavone Cossut, M.R.; Campagna, M.; Arancio, A.; et al. HIV-1 Tat Protein Enters Dysfunctional Endothelial Cells via Integrins and Renders Them Permissive to Virus Replication. Int. J. Mol. Sci. 2021, 22, 317. https://doi.org/10.3390/ ijms22010317

Received: 19 November 2020 Accepted: 26 December 2020 Published: 30 December 2020

Publisher's Note: MDPI stays neutral with regard to jurisdictional clai$\mathrm{ms}$ in published maps and institutional affiliations.

Copyright: (C) 2020 by the authors. Licensee MDPI, Basel, Switzerland. This article is an open access article distributed under the terms and conditions of the Creative Commons Attribution (CC BY) license (https:// creativecommons.org/licenses/by/ $4.0 /)$.

\begin{abstract}
Previous work has shown that the Tat protein of Human Immunodeficiency Virus (HIV)-1 is released by acutely infected cells in a biologically active form and enters dendritic cells upon the binding of its arginine-glycine-aspartic acid (RGD) domain to the $\alpha 5 \beta 1, \alpha \mathrm{v} \beta 3$, and $\alpha \mathrm{v} \beta 5$ integrins. The up-regulation/activation of these integrins occurs in endothelial cells exposed to inflammatory cytokines that are increased in HIV-infected individuals, leading to endothelial cell dysfunction. Here, we show that inflammatory cytokine-activated endothelial cells selectively bind and rapidly take up nano-micromolar concentrations of Tat, as determined by flow cytometry. Protein oxidation and low temperatures reduce Tat entry, suggesting a conformation- and energy-dependent process. Consistently, Tat entry is competed out by RGD-Tat peptides or integrin natural ligands, and it is blocked by anti- $\alpha 5 \beta 1,-\alpha \mathrm{v} \beta 3$, and $-\alpha \mathrm{v} \beta 5$ antibodies. Moreover, modelling-docking calculations identify a low-energy Tat- $\alpha \mathrm{v} \beta 3$ integrin complex in which Tat makes contacts with both the $\alpha \mathrm{v}$ and $\beta 3$ chains. It is noteworthy that internalized Tat induces HIV replication in inflammatory cytokine-treated, but not untreated, endothelial cells. Thus, endothelial cell dysfunction driven by inflammatory cytokines renders the vascular system a target of Tat, which makes endothelial cells permissive to HIV replication, adding a further layer of complexity to functionally cure and/or eradicate HIV infection.
\end{abstract}

Keywords: integrins; endothelial cells; inflammatory cytokines; HIV-1 Tat protein; cellular uptake; HIV-1 target cells

\section{Introduction}

By mediating the adhesive interactions occurring between endothelial cells and the vessel basement membrane, integrins exert important roles in either the maintenance of vascular integrity or the formation of new vessels [1,2]. Accordingly, alterations in integrin expression and/or function occur in endothelial cell dysfunction and associated morbidities [1,3-7].

Among the inducers of endothelial cell dysfunction are inflammatory mediators including interleukin (IL)- $1 \beta$, tumor necrosis factor (TNF)- $\alpha$, and interferon (IFN)- $\gamma$; of importance, these cytokines can alter the expression and/or function of integrins, such as $\alpha 5 \beta 1$ or $\alpha \mathrm{v} \beta 3$, which are key to endothelial cells [8-12]. 
In this regard, HIV-infected individuals display a chronic systemic inflammation and high IL- $1 \beta$, TNF- $\alpha$ or IFN $-\gamma$ plasma levels, even when they are treated with the combination antiretroviral therapy (cART) which reduces Human Immunodeficiency Virus (HIV)-1 replication or infectivity [13-16]. Indeed, in HIV infection, endothelial cells are chronically activated, release vascular adhesion molecules and angiogenic factors, and undergo numerous additional changes characteristic of endothelial dysfunction, which, in turn, has been proposed to contribute to the increased incidence of cardiovascular diseases observed in the pre-ART and in the ART era, respectively [17-20]. Moreover, although mainly associated to cardiovascular diseases, endothelial dysfunction occurs in all the AIDS and non-AIDS-associated morbidities [21]. In fact, abnormal angiogenesis and altered permeability of the blood-brain barrier associated to central and peripheral nervous system vasculopathies occur at high frequency in HIV infected individuals and contribute to the onset of tumors and dementia [22].

As for inflammatory cytokines, several HIV proteins continue to be expressed even during effective cART [23-27], which may contribute to endothelial dysfunction and increased cardiovascular disease risk [18-28]. Notably, the development of cardiovascular disease has been reported in mouse and rat models transgenic for HIV genes in the absence of virus replication $[29,30]$, underscoring the role of HIV proteins per se.

Of them, HIV-1 Tat, the earliest protein to be produced upon virus entry and even prior to virus integration, has been shown to severely affect endothelial cell functionality [31,32]. Although fundamental for HIV gene transcription, the majority (about $65 \%$ ) of the Tat protein synthesized during acute infection is released by the infected cells in the extracellular milieu in a biologically active form [33-36]. This occurs through exocytosis, via a leaderless secretory pathway, in the absence of cell death or cell permeability changes [33,34].

Notably, nano-micromolar concentrations of extracellular Tat protein, which are comparable to those detected in vivo in tissues, selectively enter dendritic cells upon the engagement of the $\alpha 5 \beta 1, \alpha v \beta 3$, and $\alpha v \beta 5$ integrins [37]. In doing so, Tat drives dendritic cell maturation toward a Th-1 polarizing phenotype, further modulating $\mathrm{T}$ cell responses [38]. This phenomenon greatly differs from the ability of micromolar concentrations of Tat to enter virtually all cell types via the binding of Tat basic residues to the heparan-sulfate proteoglycans (HSPG) of the cell membrane [39].

In addition to dendritic cells, Tat influences also endothelial cells, and this occurs through a variety of modes [31,32]. As first, it is noteworthy that the extracellular Tat protein can promote the locomotion, adhesion, and growth of endothelial cells after their activation with TNF- $\alpha$, IL- $1 \beta$, and IFN- $\gamma$, which increase the expression or activity of the arginine-glycine-aspartic acid (RGD)-binding $\alpha 5 \beta 1$ and $\alpha \mathrm{v} \beta 3$ integrins [40-42]. In doing so, Tat increases the frequency and expressiveness of Kaposi's sarcoma (KS), an angioproliferative tumor frequent in HIV-infected individuals [41,43,44]. The finding that Tat, $\alpha v \beta 3$, and $\alpha 5 \beta 1$ are highly expressed in AIDS-associated KS lesions [39] suggests that these mechanisms are indeed operating in vivo.

In this context, it is worth noticing that Tat itself can directly induce the expression of inflammatory cytokines [45-49]. Tat also increases leukocyte adhesiveness to endothelial cells and trans-endothelial migration, as it induces the expression of intercellular adhesion molecule-1 (ICAM-1), vascular adhesion molecule-1, and E-selectin on the endothelial cell surface [50]. In addition to favoring the extravascular dissemination of HIV-1, the newly synthesized adhesion molecules place HIV-infected leukocytes in close proximity with endothelial cells.

Based on this evidence, here, we have evaluated whether extracellular Tat protein could enter endothelial cells via the $\alpha 5 \beta 1, \alpha \mathrm{v} \beta 3$, or $\alpha \mathrm{v} \beta 5$ integrins, and whether this could support HIV replication in these otherwise poorly susceptible cells. 


\section{Results}

2.1. Biologically Active Tat Enters Primary Endothelial Cells in a Dose-, Time-, and Activation-Dependent Fashion

To determine whether the Tat protein of HIV-1 could enter quiescent and/or activated endothelial cells, primary human umbilical vein endothelial cells (HUVEC) were cultured in the presence or absence of human recombinant IL- $1 \beta$, TNF- $\alpha$, and IFN- $\gamma$, which were combined at doses as found in inflammatory microenvironments. Endothelial cell activation was confirmed throughout the course of the whole study by evaluating the cell surface expression of ICAM-1 (CD54), which was $>90 \%$ (data not shown).

HUVEC, both inflammatory cytokine (IC)-activated (IC-HUVEC) and non-activated (HUVEC), were incubated in suspension with biologically active Tat protein at concentrations compatible with those detected in specimens from HIV-infected individuals [51-54]. Then, the intracellular Tat content was evaluated by staining with anti-Tat antibodies ( $\mathrm{Ab}$ ) and flow cytometry.

Tat entered IC-HUVEC very rapidly and in a dose-dependent fashion. Specifically, when IC-HUVEC were exposed for $10 \mathrm{~min}$ to $1,10,100$, or $1000 \mathrm{ng} / \mathrm{mL}$ of Tat, the percentage of positive cells was 29,51,71, and $89 \%$, respectively (Figure 1A). In sharp contrast, the proportion of untreated HUVEC taking up Tat was virtually absent at low (nanomolar) Tat concentrations (1-10 ng/mL), whereas only $22 \%$ of HUVEC stained positive at Tat $1000 \mathrm{ng} / \mathrm{mL}$ (Figure 1A). Thus, IC-HUVEC internalized the Tat protein much more efficiently than HUVEC at all Tat concentrations tested $(p=0.0404)$. Based on these results, IC-HUVEC were chosen for the subsequent experiments.

Then, time course experiments were performed to determine the kinetics of Tat entry. Of interest, irrespective of the protein concentration, Tat uptake by IC-HUVEC was already maximal after the shortest time ( $5 \mathrm{~min}$ ) of exposure to the protein, and it started to slowly decline after $30 \mathrm{~min}$, except for the highest Tat concentration (Figure S1). In this regard, virtually all cells (>95\%) stained positive for intracellular Tat upon 5 min exposure to $1000 \mathrm{ng} / \mathrm{mL}$ of the protein, and no changes were recorded at the subsequent time points (Figure S1), suggesting the involvement of different receptor(s) and/or pathway(s) of internalization and processing of the protein, as previously reported to occur for monocytederived dendritic cells [37].

Anti-Tat Abs did not stain non-permeabilized cells incubated with Tat (data not shown), indicating that (i) cell surface-bound Tat was totally removed by treating cells with trypsin; (ii) most protein was internalized; and (iii) neither the trypsin used to remove cell surface-bound Tat nor the non-enzymatic procedure utilized to suspend IC-HUVEC altered the cell membrane permeability.

However, to rule out the interference of cell detachment or trypsinization in the Tat uptake process, adherent IC-HUVEC were exposed to rhodamine-labeled Tat. Then, entry of the protein was visualized by confocal microscopy, as described in Section 4 Materials and Methods. As shown in Figure 1B, the orthogonal view revealed the presence of Tat in an introflexion of the nucleus, which is a finding supported by the tomographic analysis of the confocal image (Figure S2). Taken together, the data indicate that biologically active Tat enters both suspended and adherent cells. 
A

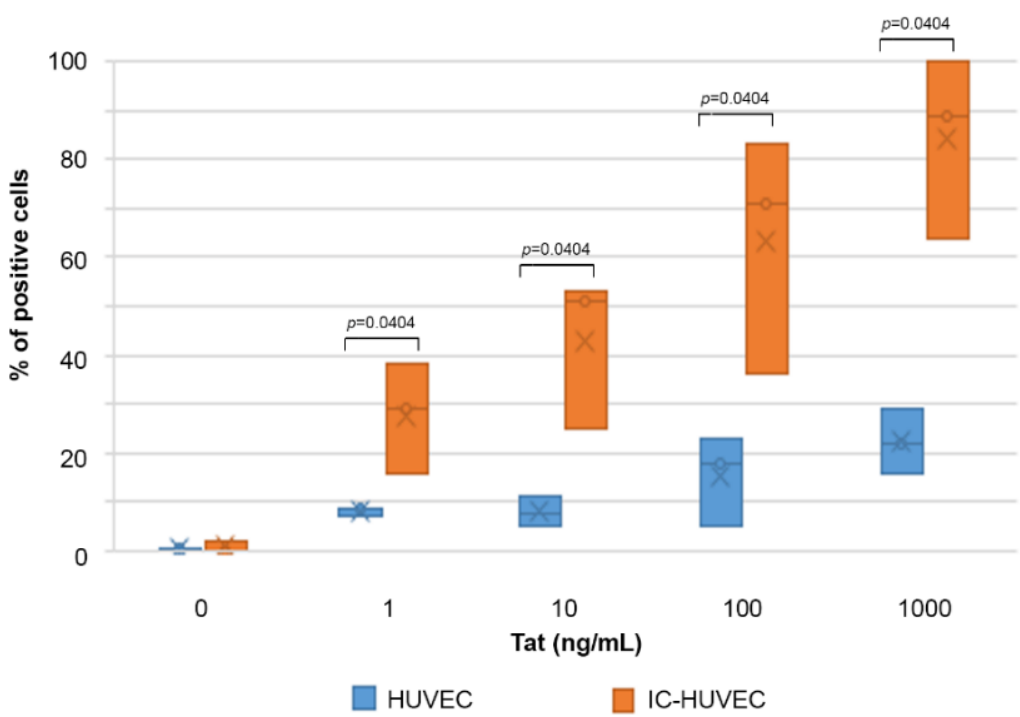

B

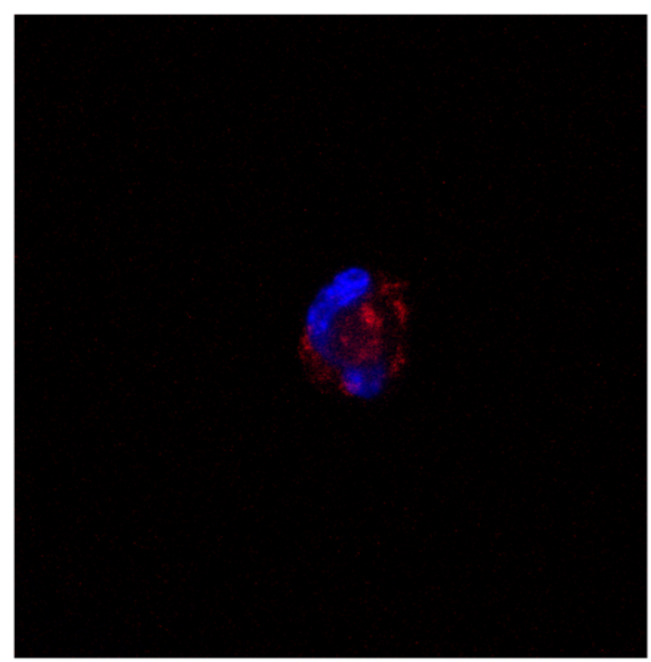

C

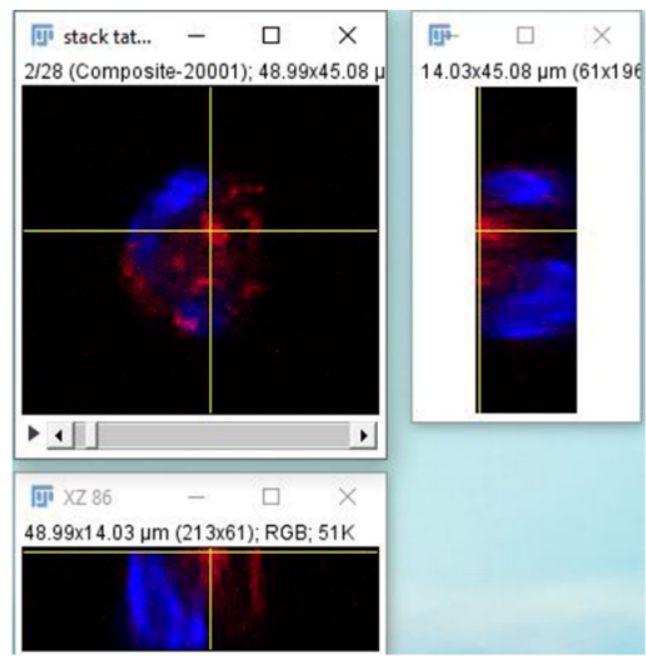

Figure 1. Extracellular Tat protein is efficiently taken up by activated endothelial cells. In (A) human umbilical vein endothelial cells (HUVEC, blue plots) or inflammatory cytokine (IC)-activated (IC-HUVEC (orange plots) were incubated for $10 \mathrm{~min}$ in medium containing serial concentrations $(1-1000 \mathrm{ng} / \mathrm{mL}$ ) of biologically active Tat or its suspension buffer (PBS-0.1\% BSA). Intracellular Tat content was evaluated by flow cytometry after staining with affinity-purified rabbit anti-Tat polyclonal Ab (or isotype control), as described in Section 4 Materials and Methods. Non-permeabilized cells were employed as an additional control. Results are expressed as the percentage of positive cells, as compared to isotype-stained samples. Box-plot of data obtained from three independent experiments and analyzed by the Mann-Whitney nonparametric test are shown. Dots indicate individual measures. In (B,C), IC-HUVEC were incubated with rhodamine-labeled Tat (100 ng/mL) and treated as described in Section 4 Materials and Methods. Images are optical sections (optical thickness $=0.40 \mu \mathrm{m}$ ) collected from a confocal microscope showing cellular internalization of Tat (red). Blue indicates nuclei stained with DAPI. Scale bar $=15 \mu \mathrm{m}$.

\subsection{Tat Entry in IC-HUVEC Is Reduced by Low Temperature or Tat Oxidation}

To further characterize the entry of Tat in IC-HUVEC, cells were exposed to different temperatures. In fact, previous work indicated that Tat uptake by human tumor cell lines or dendritic cells is strongly reduced or lost at low temperatures, or upon Tat oxidation and inactivation $[37,55]$. In agreement with these findings, the entry of Tat into IC-HUVEC was strongly reduced at $4^{\circ} \mathrm{C}$ as compared to $37^{\circ} \mathrm{C}$. In particular, the entry of 1 or $10 \mathrm{ng} / \mathrm{mL}$ 
Tat into IC-HUVEC was inhibited by 64 and $57 \%$, respectively, while cellular uptake of 100 or $1000 \mathrm{ng} / \mathrm{mL}$ Tat was reduced by 53\% ( $p=0.0404$, Figure $2 \mathrm{~A})$.

A

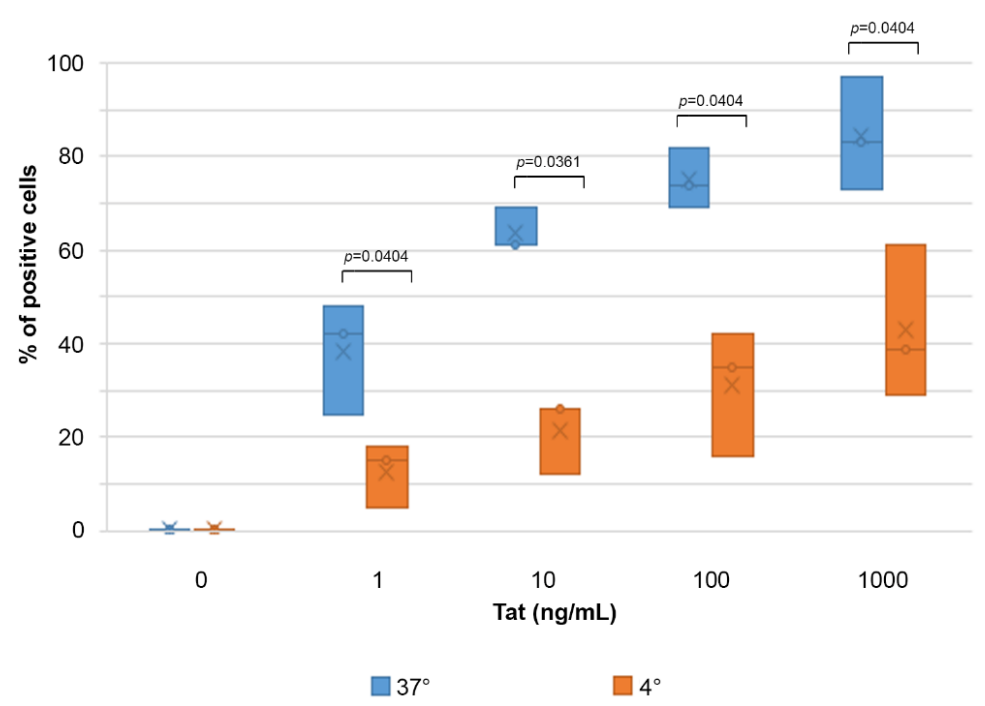

B

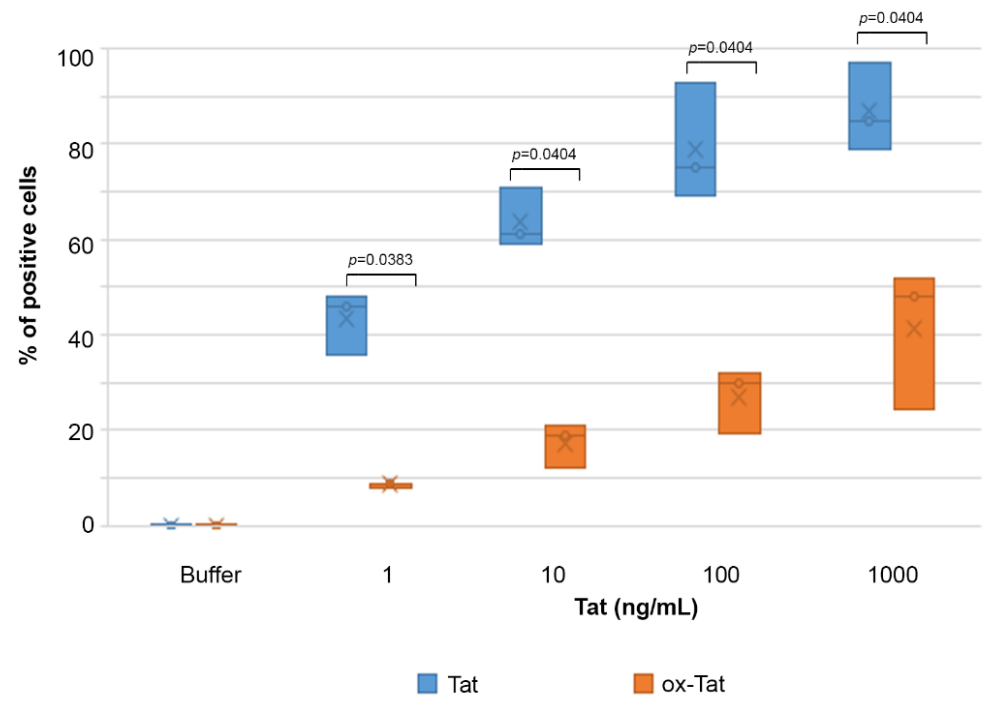

Figure 2. Entry of Tat in IC-HUVEC is reduced by low temperatures or Tat oxidation. (A) IC-activated HUVEC were incubated for $10 \mathrm{~min}$ at $37^{\circ} \mathrm{C}$ (blue plots) or $4{ }^{\circ} \mathrm{C}$ (orange plots) with biologically active Tat (1-1000 ng/mL) or its buffer (0 ng/mL). (B) IC-HUVEC were incubated for $10 \mathrm{~min}$ with 1-1000 $\mathrm{ng} / \mathrm{mL}$ of biologically active (blue plots) or inactive, oxidized (orange plots) Tat. For both (A,B), the detection of intracellular Tat was performed as described in the legend to Figure 1, and the results are expressed as the percentage of positive cells. Box-plot of data obtained from three independent experiments and analyzed by the Mann-Whitney test are shown. Dots indicate individual measures. In all experiments, the fluorescence of permeabilized cells stained with anti-Tat Ab was compared to that of isotype-stained samples and non-permeabilized cells.

Similarly, a marked reduction of Tat entry was observed upon Tat protein inactivation by oxidation (see Section 4 Materials and Methods). In fact, the entry of 1, 10, 100, or $1000 \mathrm{ng} / \mathrm{mL}$ of oxidized Tat into IC-HUVEC was reduced by $80,69,60$, and $44 \%$, respectively, as compared to native, biologically active Tat ( $p<0.05$, Figure 2B).

Taken together, these results indicate that an efficient uptake of Tat by IC-HUVEC requires a biologically active protein and it is likely to occur through receptor-mediated 
endocytosis, which is an energy-dependent process that is reduced at low temperatures, although additional pathway(s) may exist for higher Tat concentrations.

2.3. Uptake of Tat by Activated HUVEC Requires Both the RGD Domain and the Basic Region of Tat, and It Is Competed by Fibronectin and Vitronectin

Then, blocking experiments were performed to identify the Tat domains involved in the uptake of Tat by IC-HUVEC. Specifically, IC-HUVEC were incubated with a molar excess of Tat or Tat peptides spanning either the Tat RGD domain (Tat-RGD aa 66-80) or the Tat basic region (Tat-BASIC, aa 46-60). The peptide spanning the acidic domain of Tat (TatACIDIC, aa 11-25) was used as control, since this Tat region does not bind the endothelial cell membrane [39-41,56,57]. Incubation with competitor peptides was followed by the addition of Tat at concentrations ranging from 1 to $1000 \mathrm{ng} / \mathrm{mL}$. As shown in Figure $3 \mathrm{~A}$, the pre-incubation of IC-HUVEC with Tat-ACIDIC did not affect cellular uptake of any of the Tat concentrations tested. In contrast, prior incubation with Tat-RGD abolished IC-HUVEC uptake of 1 and $10 \mathrm{ng} / \mathrm{mL}$ of Tat, while the entry of 100 and $1000 \mathrm{ng} / \mathrm{mL}$ Tat was reduced by 56 and $29 \%$, respectively ( $p=0.0011$ and $p=0.0010$, Figure $3 \mathrm{~A}$ ). At variance with the Tat-RGD peptide, the Tat-BASIC peptide had no effect on the uptake of 1 and $10 \mathrm{ng} / \mathrm{mL}$ of Tat, whereas it reduced the uptake of 100 and $1000 \mathrm{ng} / \mathrm{mL}$ Tat by 44 and $65 \%$, respectively ( $p=0.0580$ and $p=0.0178$, Figure $3 \mathrm{~A}$ ). Consistent with these findings, the prior incubation of IC-HUVEC with combined Tat-BASIC and Tat-RGD peptides abolished the entry of Tat 1,10 , and $100 \mathrm{ng} / \mathrm{mL}$, and it strongly reduced $(-93 \%)$ the uptake of $1000 \mathrm{ng} / \mathrm{mL}$ of Tat $(p=0.0060$, Figure 3A).

To verify whether Tat entry in IC-HUVEC is mediated by RGD-binding integrins, fibronectin and vitronectin, the natural ligands of these receptors, were used as competitors. Pre-incubation with fibronectin and vitronectin abolished IC-HUVEC uptake of $1 \mathrm{ng} / \mathrm{mL}$ Tat and reduced the uptake of 10,100 , and $1000 \mathrm{ng} / \mathrm{mL}$ Tat by 89,76 , and $61 \%$, respectively ( $p=0.0404$, Figure 3B). This indicated that RGD-binding integrins are required for Tat entry and confirmed that at nano-micromolar concentrations, Tat entry is strictly dependent on the RGD domain of Tat.

Thus, the entry of low doses of Tat appears to be mediated exclusively by the Tat RGD region, whereas both the RGD and the basic region are involved in the entry of high concentrations of Tat.

2.4. Tat Entry in IC-HUVEC Is Blocked by Monoclonal Antibodies against the $\alpha 5 \beta 1, \alpha v \beta 3$, and $\alpha v \beta 5$ Integrins

Following the identification of the Tat domains that mediate the uptake of the protein by IC-HUVEC, intracellular staining and flow cytometry were employed to assess whether Tat entry into IC-HUVEC could be inhibited by monoclonal antibodies (mAbs) directed against the RGD-binding integrins $\alpha 5 \beta 1$ or $\alpha \mathrm{v} \beta 3$. MAbs were employed at a concentration $(5 \mu \mathrm{g} / \mathrm{mL})$ that abolishes IC-HUVEC adhesion onto immobilized fibronectin or vitronectin (data not shown). A mAb directed against the endothelial cell marker CD31 was employed as a control of specificity.

Results indicated that while the prior incubation of IC-HUVEC with anti-CD31 mAb had no effect on the uptake of Tat, at all Tat concentrations tested (Figure $4 \mathrm{~A}$ ), prior incubation of IC-HUVEC with anti- $\alpha 5 \beta 1$ or anti- $\alpha \mathrm{v} \beta 3 \mathrm{mAbs}$ inhibited to a comparable extent the entry of Tat, and the inhibition was again more pronounced at the low Tat concentrations ( $p=0.0404$ and $p=0.0152$ respectively, Figure $4 \mathrm{~A})$. When anti- $\alpha 5 \beta 1$ and anti$\alpha \mathrm{v} \beta 3 \mathrm{mAbs}$ were combined, a higher inhibitory effect was observed at all Tat concentrations $(p<0.05$, Figure 4A). Thus, mAbs directed against the RGD-binding $\alpha 5 \beta 1$ and $\alpha v \beta 3$ integrins effectively competed out Tat binding to IC-HUVEC and specifically abolished the entry of low Tat amounts. In substantial agreement with the results obtained with the Tat RGD peptide, the inhibition was only partial at the highest Tat concentrations, even when anti- $\alpha 5 \beta 1$ and anti- $\alpha \mathrm{v} \beta 3 \mathrm{mAbs}$ were used in combination. 
A
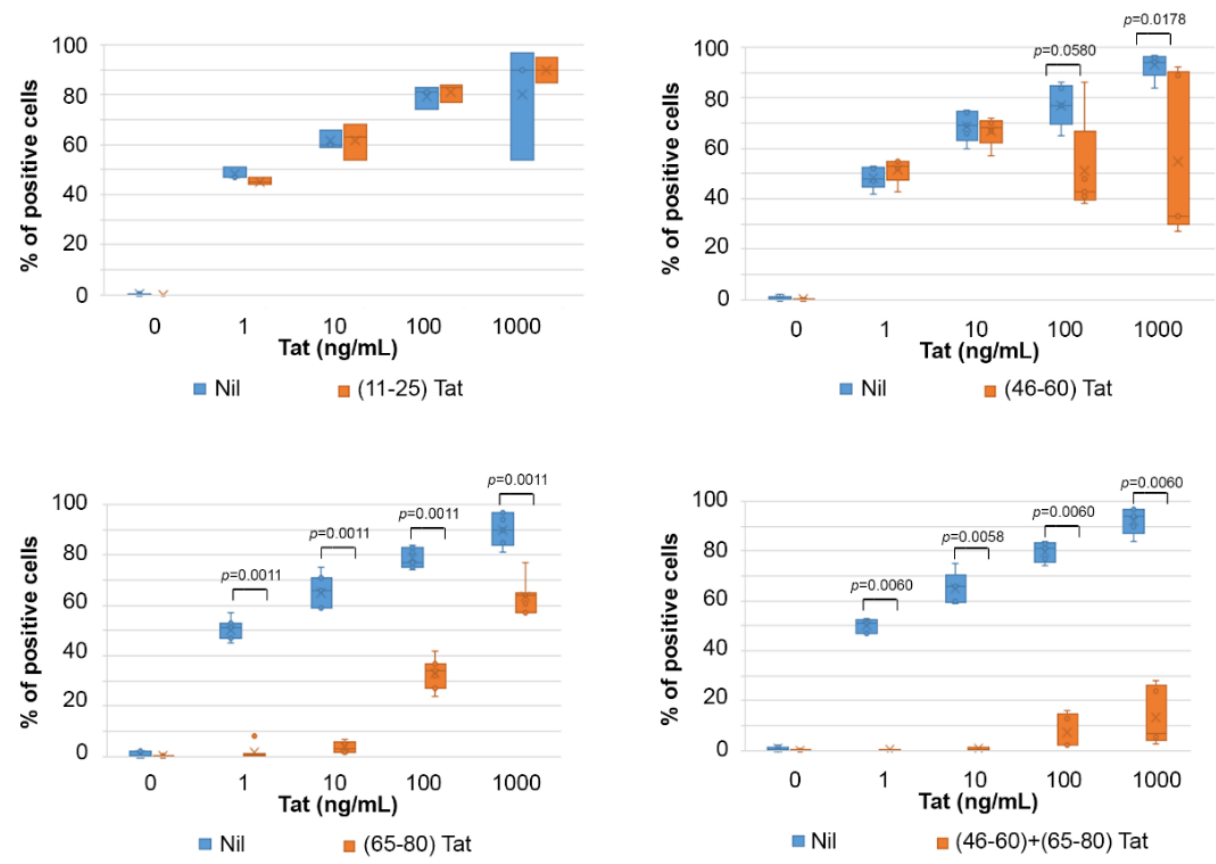

B

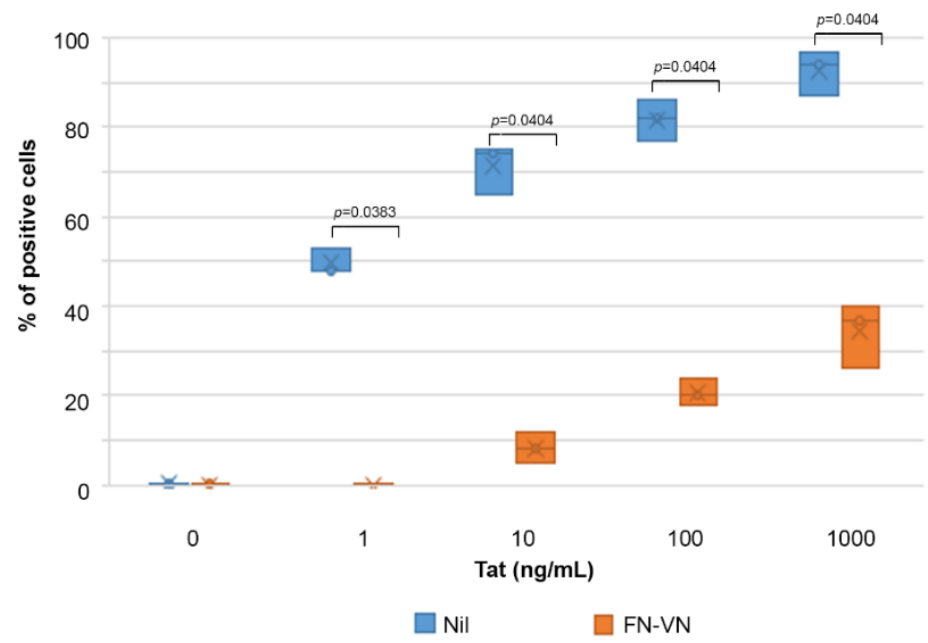

Figure 3. Role of Tat arginine-glycine-aspartic acid (RGD) and basic region in entry of Tat in IC-HUVEC, and entry blockade by fibronectin and vitronectin. In (A), IC-HUVEC were incubated for $2 \mathrm{~h}$ with $100 \mu \mathrm{g} / \mathrm{mL}$ of the (11-25) Tat-ACIDIC (upper left panel), (46-60) Tat-BASIC (upper right panel), (66-80) Tat-RGD (lower left panel) or combined (46-60) Tat and (66-80) Tat (lower right panel) peptides. Cells incubated with the peptide suspension buffer (PBS-0.1\% BSA) were employed as controls. In (B), IC-HUVEC were incubated for $2 \mathrm{~h}$ with fibronectin (FN) and vitronectin (VN), combined at $50 \mu \mathrm{g} / \mathrm{mL}$ each. FN and VN dilution buffer (PBS-0.1\% BSA) served as a negative control (Nil). For both (A,B), after pre-incubation, IC-HUVEC were exposed for $10 \mathrm{~min}$ to biologically active Tat (1-1000 ng/mL) or its suspension buffer (Nil). Intracellular Tat content was assessed by intracellular staining and flow cytometry as described in the legend to Figure 1. Results are expressed as the percentage of positive cells as compared to isotype-stained samples and non-permeabilized cells. Box-plot data obtained from three to six independent experiments and analyzed by the Mann-Whitney test are shown. Dots in box-plots indicate individual measures. Orange plots refer to IC-HUVEC incubated with Tat peptides (A) or combined FN and VN (B); blue plots refer to control IC-HUVEC. 
A
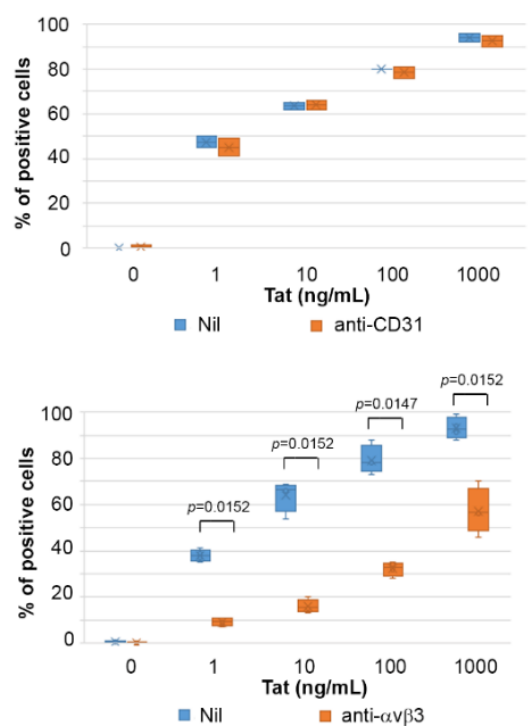

B
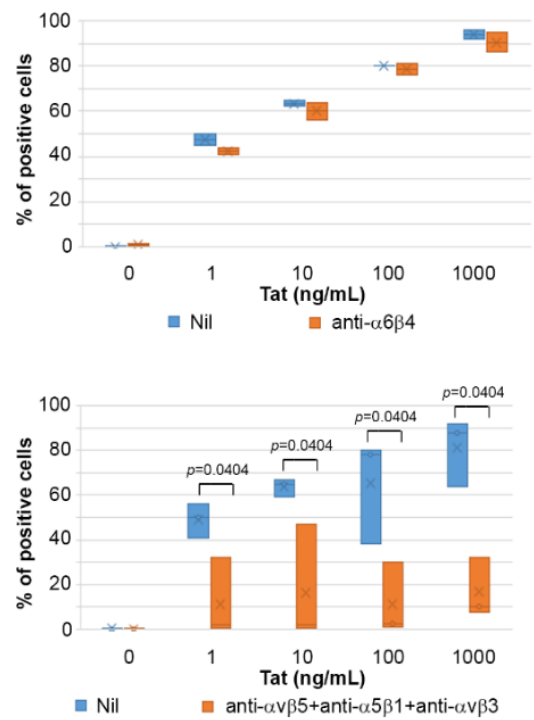
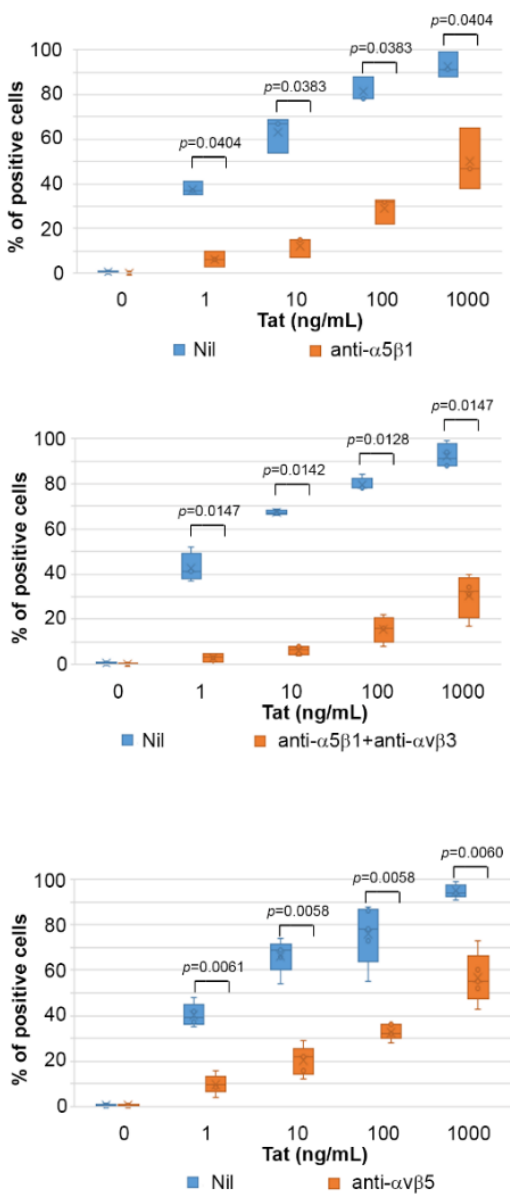

Figure 4. Blockade of Tat entry in IC-HUVEC by antibodies directed against the $\alpha 5 \beta 1, \alpha \mathrm{v} \beta 3$, and/or $\alpha \mathrm{v} \beta 5$ integrin. In (A), activated HUVEC were suspended and then incubated for $2 \mathrm{~h}$ with $5 \mu \mathrm{g} / \mathrm{mL}$ of monoclonal antibodies (mAb) directed against CD31 (upper left panel), $\alpha 5 \beta 1$ (upper right panel), or $\alpha \mathrm{v} \beta 3$ (lower left panel), or with anti- $\alpha 5 \beta 1$ and anti- $\alpha \mathrm{v} \beta 3 \mathrm{mAb}$, combined together at $5 \mu \mathrm{g} / \mathrm{mL}$ each (lower right panel). In (B), IC-HUVEC were suspended and then incubated for $2 \mathrm{~h}$ with $5 \mu \mathrm{g} / \mathrm{mL}$ of anti- $\alpha 6 \beta 4 \mathrm{mAb}$ (upper left panel), or with $5 \mu \mathrm{g} / \mathrm{mL}$ of anti- $\alpha \mathrm{v} \beta 5 \mathrm{mAb}$, alone (upper right panel) or combined with anti- $\alpha 5 \beta 1$ and anti- $\alpha v \beta 3 \mathrm{mAb}$ (lower panel). For both (A,B), IC-HUVEC incubated with Ab dilution buffer (PBS-0.1\% BSA) were employed as controls (Nil). After incubation, IC-HUVEC was exposed for 10 min to biologically active Tat (1-1000 ng/mL) or its buffer. Intracellular Tat content was assayed by intracellular staining and flow cytometry as described. Results are expressed as the percentage of positive cells as compared to isotype-stained samples and non-permeabilized cells. Box-plot data obtained from three to four independent experiments and analyzed by the Mann-Whitney test are shown. Dots indicate individual measures. Orange plots refer to IC-HUVEC incubated with the said mAbs; blue plots refer to control IC-HUVEC.

To further investigate the contribution of RGD-binding integrins to Tat entry into IC-HUVEC, the role of $\alpha v \beta 5$ was also evaluated, since this integrin has been reported to bind both the basic domain and the RGD region of cellular or microbial molecules [58,59]. Antibodies directed against the laminin receptor $\alpha 6 \beta 4$, which does not belong to the group 
of RGD-binding integrins [60], were employed as a control. Results indicated that preincubation with the anti- $\alpha \mathrm{v} \beta 5 \mathrm{mAb}$, but not with anti- $\alpha 6 \beta 4 \mathrm{mAb}$, inhibited IC-HUVEC uptake of $1,10,100$, and $1000 \mathrm{ng} / \mathrm{mL}$ of Tat by $75,68,59$, and $41 \%$, respectively ( $p<0.05$ for all, Figure 4B).

Of note, when IC-HUVEC were pre-incubated with saturating amounts of mAbs directed against all the three RGD-binding integrins $\alpha 5 \beta 1, \alpha v \beta 3$, and $\alpha v \beta 5$, virtually no Tat uptake was observed up to the $100 \mathrm{ng} / \mathrm{mL}$ concentration of Tat, while at the highest concentration tested $(1000 \mathrm{ng} / \mathrm{mL})$, Tat entry was reduced by $89 \%(p=0.0404$, Figure $4 \mathrm{~B})$.

Altogether, these results indicate that $\alpha 5 \beta 1, \alpha \mathrm{v} \beta 3$, and $\alpha \mathrm{v} \beta 5$ integrin receptors mediate to a similar extent the entry of Tat in IC-HUVEC, and that the blockade of all of them is required to abolish the binding and entry of Tat at all concentrations used, which appears to be strictly dependent on the Tat RGD domain for the integrins $\alpha 5 \beta 1$ and $\alpha \mathrm{v} \beta 3$, and (conceivably) on both Tat basic and RGD domains for the integrin $\alpha v \beta 5$.

\subsection{The Tat RGD Domain Is Exposed and Binds $\alpha v \beta 3$ in Modeling-Docking of Tat-Integrin Interaction}

To gain more insights into the Tat binding to integrins, structural models of the interaction between Tat and $\alpha v \beta 3$ were generated using the $X$-ray structure of the integrin $\alpha v \beta 3$ in complex with an RGD-containing cyclic peptide [61] through docking calculations. To this purpose, three structural models were built for Tat using three experimental structures available for different strains [62]. Despite their high sequence identity, these structures showed different conformations where the RGD sequence was exposed or partially or almost completely buried. When the RGD was buried, only high-energy complexes between integrin $\alpha \mathrm{v} \beta 3$ and Tat were obtained, indicating that these Tat conformations are not able to induce productive binding with the integrin. Conversely, one cluster of low-energy complexes was obtained with the Tat conformation exposing the RGD sequence. Of note, in all complexes of this cluster, Tat makes contact with both the $\alpha \mathrm{v}$ and the $\beta 3$ subunits (Figure 5A).

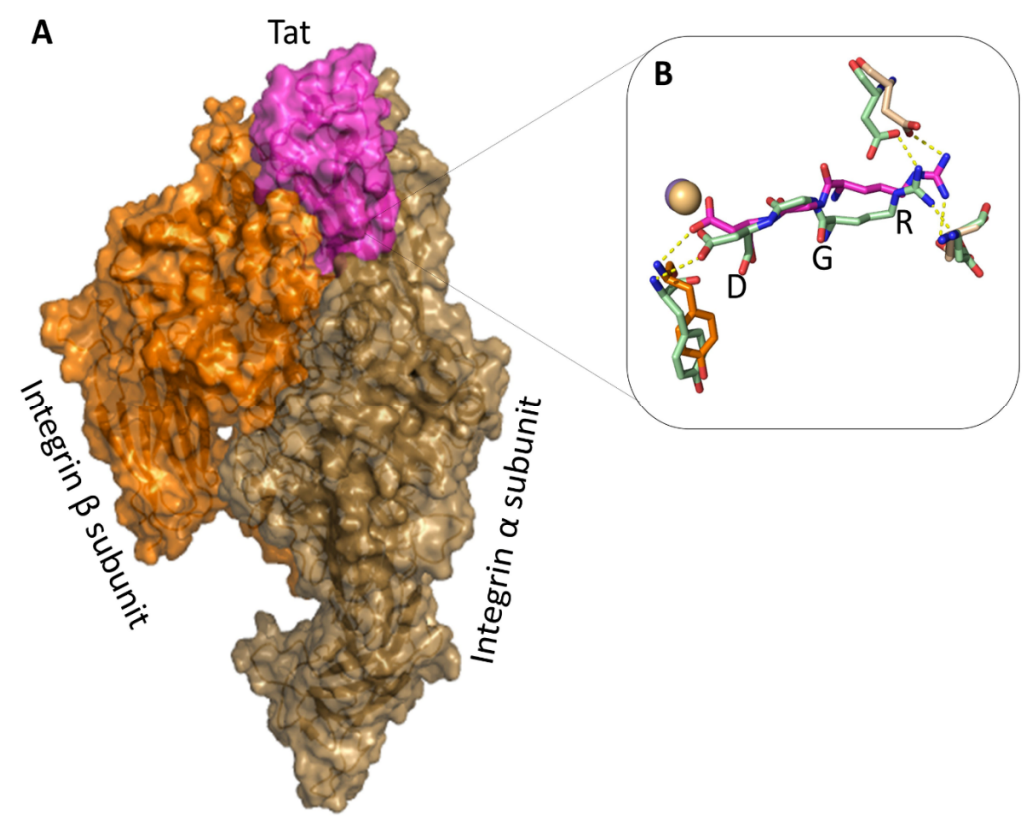

Figure 5. Tat makes contacts with both the $\alpha$ and $\beta$ chains of $\alpha \mathrm{v} \beta 3$. (A) Average structural model of the Tat- $\alpha v \beta 3$-integrin complex structure. Tat (magenta) interacts with both integrin subunits (brown $=\alpha$; orange $=\beta$ ). (B) The calculated structural model of the $\alpha v \beta 3$-Tat protein complex (magenta) is compared to the experimental structure of the $\alpha v \beta 3-R G D$ containing cyclic peptide complex (light green). Conserved hydrogen bonds between the two structures are shown. The metal ion interacting with the RGD fragment is represented as a sphere. 
In this low energy structural model, the Tat RGD region is inserted into the crevice between the $\beta$-propeller and the $\beta$ A domains of the $\alpha v \beta 3$, as observed in the $X$-ray structure of the complex between the RGD-containing cyclic peptide and $\alpha \mathrm{v} \beta 3$ (Figure 5B) [61]. Furthermore, as for the RGD cyclopeptide, Tat Asp80 interacts with the metal ion of the integrin $\beta$ A domain and with Tyr1122 of the integrin $\beta$ subunit, whereas Tat Arg78 interacts with both Asp150 and Asp218 of the integrin $\alpha$ chain (Table 1).

Table 1. Intermolecular H-bonds conserved in at least four of the ten lowest-energy models for the Tat-integrin complex structures.

\begin{tabular}{ccc}
\hline Tat-Interacting Residues & Integrin-Interacting Residues & Interaction Type \\
\hline 17-GLN & 1126-ASP & SC-SC H-bond \\
56-ARG & $1180-\mathrm{MET}$ & MC-SC H-bond \\
62-SER & $1214-\mathrm{ARG}$ & SC-SC H-bond \\
75-SER & $178-\mathrm{TYR}$ & SC-SC H-bond \\
78-ARG & $\mathbf{1 5 0 - A S P}$ & SC-SC H-bond \\
78-ARG * & $\mathbf{2 1 8 - A S P *}$ & SC-SC H-bond \\
80-ASP & $\mathbf{1 1 2 2 - T Y R}$ & SC-MC H-bond \\
80-ASP & 4001-MN2+ & SC-Mt bond \\
80-ASP & $1123-S E R$ & SC-MC H-bond \\
86-GLU & 248-ARG & SC-SC H-bond \\
86-GLU & 1253-LYS & SC-SC H-bond \\
\hline
\end{tabular}

* Bidentate interactions. Experimentally reported interactions [61] between the RGD domain of Tat and the integrin are shown in bold; Residues of the $\alpha_{\mathrm{v}}$ integrin chain are numbered from 1 to 956 , residues of the $\beta_{3}$ integrin chain are numbered from 1055 to 1690; SC = side chain; $\mathrm{MC}=$ main chain.

Additional contacts, such as hydrogen bonds and hydrophobic interactions, are present between the C-terminal region of Tat and both integrin subunits (Table 1). Furthermore, Tat Glu86 forms two salt bridges with the side chains of Arg248 and Lys1253 in the two integrin's chains. These data suggest that the last 31 residues of Tat (56-86) containing the RGD sequence are the most important for the Tat-integrin interaction. Electrostatic complementarity of the surfaces on the two partner proteins appears to further stabilize the complex. No residue of the basic region, with the only exception of Arg56, interacts with the integrin in this model.

\subsection{Tat Mediates Productive HIV-1 Infection of IC-HUVEC}

To evaluate whether Tat entry could have an impact on endothelial cell susceptibility to HIV-1 infection, IC-activated or control HUVEC were exposed to NL4.3, a clade B X4tropic virus, in the absence or presence of $1 \mu \mathrm{M}(10 \mu \mathrm{g} / \mathrm{mL})$ of biologically active Tat versus a mutated Tat protein devoid of trans-activating capability (Tat ${ }_{\text {cys22 }}$ ) that was employed as control.

In non-activated HUVEC, HIV-1 entry was undetectable in the absence of Tat and barely detectable in the presence of Tat (p24-Gag+ cells: 3.5\%) or Tat cys22 $_{\text {(p24-Gag+ cells: }}$ $2.2 \%$ ) (Figure 6). Similarly, a negligible proportion of IC-HUVEC stained positive for p24-Gag in the absence of Tat (p24-Gag+ cells: 1.5\%); however, when the infection was carried out in the presence of biologically active Tat, $23.9 \%$ of the cells stained positive for intracellular p24-Gag in flow cytometry (Figure 6). This proportion was 5-fold higher than

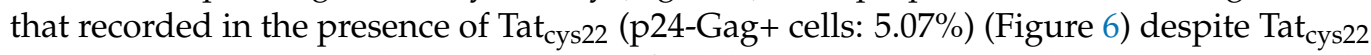
entering IC-HUVEC to the same extent of wild-type Tat (data not shown), as previously observed with dendritic cells [37]. 


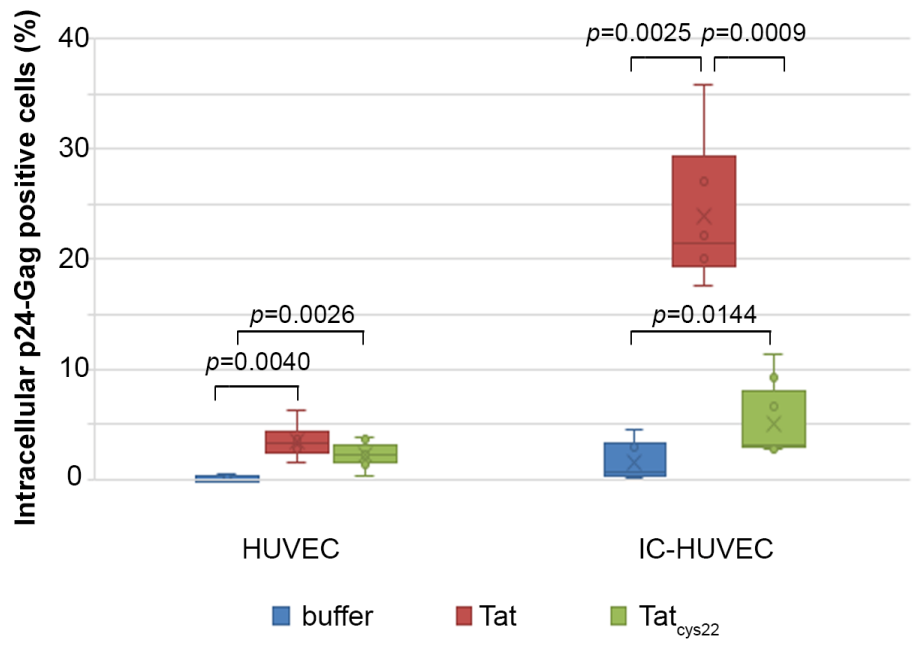

Figure 6. Extracellular Tat protein promotes productive Human Immunodeficiency Virus (HIV-1) infection of IC-HUVEC. HUVEC or IC-HUVEC were exposed to NL4.3 virus (p24-Gag = $70 \mathrm{ng} / \mathrm{mL}$ ) in the absence or in the presence of $1 \mu \mathrm{M}(10 \mu \mathrm{g} / \mathrm{mL})$ of the Tat protein, either biologically active (Tat), or devoid of transactivating activity (Tat cys22 $_{2}$. Four days later, cells were washed, trypsinized, and processed for intracellular staining for p24-Gag antigen. Box-plot data obtained from three independent experiments and analyzed by the Wilcoxon Two-sample Test are shown. Dots indicate individual measures.

Of importance, the infection was sustained and spread to neighbor cells over time, as the proportion of infected IC-HUVEC doubled from day $4(12 \%)$ to day $8(25 \%)$ postinfection even after cell trypsinization and reseeding at day 4 (Figure 7).

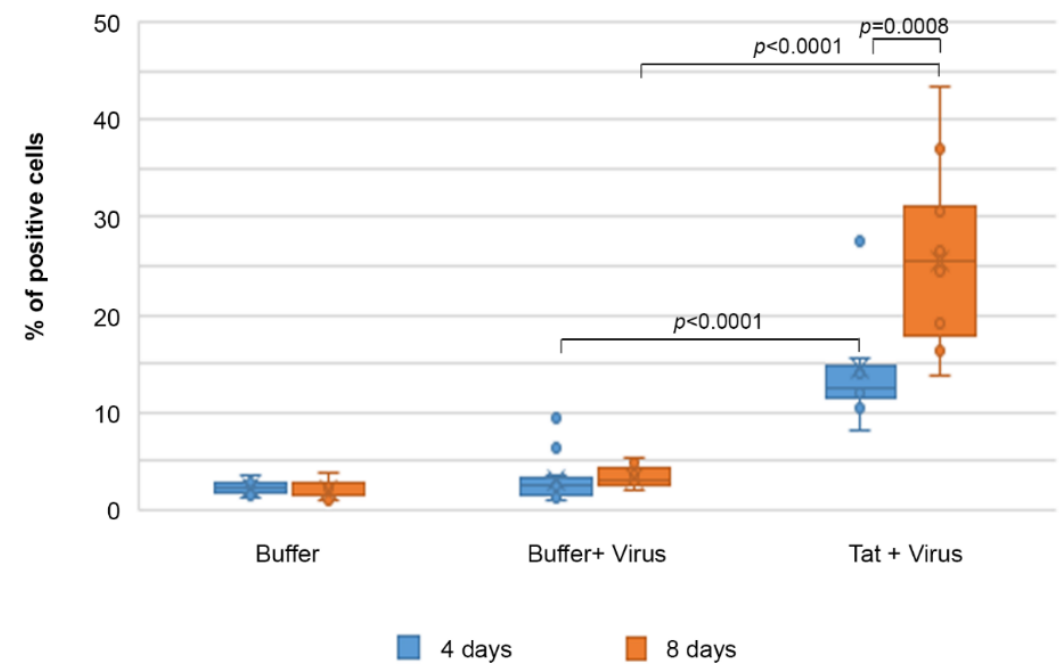

Figure 7. Extracellular Tat protein promotes productive HIV-1 infection of IC-HUVEC. IC-HUVEC were exposed to NL4.3 virus ( $\mathrm{p} 24-\mathrm{Gag}=70 \mathrm{ng} / \mathrm{mL}$ ) in the absence or in the presence of $10 \mu \mathrm{g} / \mathrm{mL}$ of biologically active Tat protein (Tat). Four and 8 days later, cells were washed, trypsinized, and processed for intracellular staining for p24-Gag antigen. Box-plot of data obtained from five independent experiments and analyzed by the Wilcoxon Two-sample Test are shown. Dots indicate individual measures.

Thus, HUVEC pre-activated with inflammatory cytokines become susceptible to HIV-1 productive infection only in the presence of biologically active Tat, indicating that it retains its biological activity upon entry and it trans-activates the incoming virus, ensuring the productive infection of endothelial cells. 


\subsection{Efavirenz Suppresses the Tat-Mediated HIV-1 Infection of IC-HUVEC}

To further verify whether the intracellular p24 detected into IC-HUVEC upon exposure to Tat was indeed a productive infection, experiments were carried out in the presence of the HIV-reverse transcriptase inhibitor Efavirenz. As shown in Figure 8, pretreatment with Efavirenz reduced from $35.4 \%$ to $10.1 \%$ the percentage of p24 Gag+ cells detected at day 4 in the presence of Tat protein, confirming that the main effect of Tat on IC-HUVEC is to promote productive HIV infection. Thus, Tat enters IC-HUVEC upon binding to RGD-binding integrins at pico-nanomolar concentrations and to HSPG at higher (micromolar) concentrations. Once internalized, Tat transactivates HIV gene expression, turning endothelial cells from a poorly susceptible to a relatively highly permissive phenotype and source of new virus production.

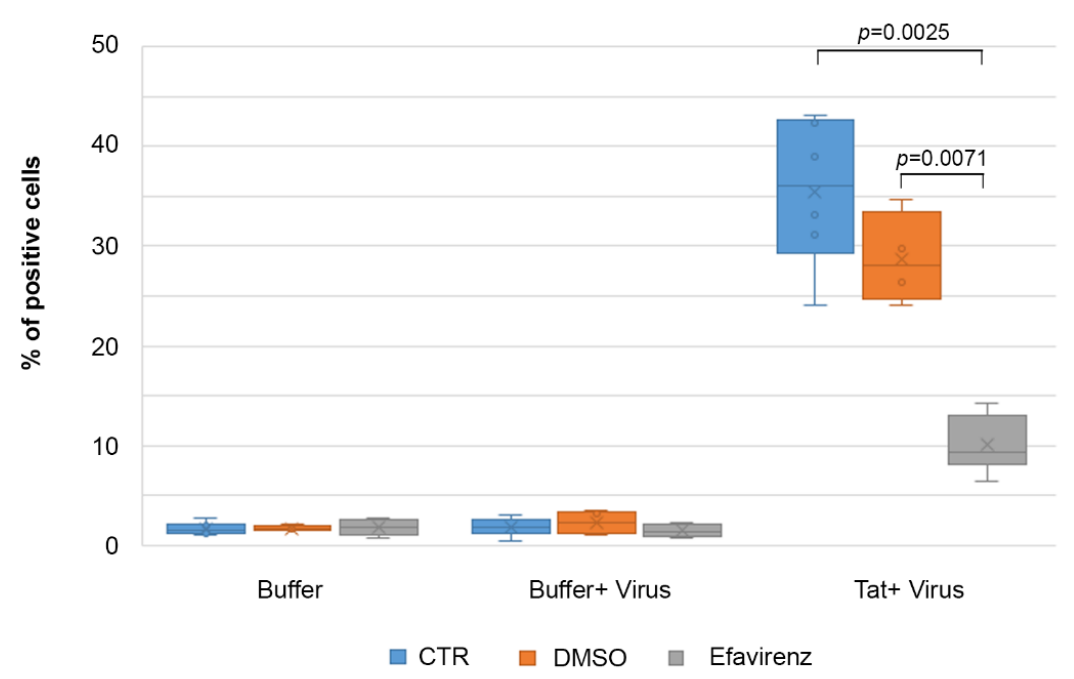

Figure 8. Efavirenz blocks HIV-1 productive infection of IC-HUVEC promoted by extracellular Tat protein. IC-HUVEC were pre-treated with Efavirenz $(500 \mathrm{nM})$ or its resuspension buffer $(0.005 \%$ DMSO) for $1 \mathrm{~h}$ prior to virus infection; then, they were exposed in the presence of the drug to NL4.3 virus (p24-Gag $=70 \mathrm{ng} / \mathrm{mL}$ ), in the absence or in the presence of $10 \mu \mathrm{g} / \mathrm{mL}$ of biologically active Tat protein (Tat). Four days later, cells were washed, trypsinized, and processed for intracellular staining for p24-Gag antigen. Box-plot of data obtained from three independent experiments and analyzed by the Wilcoxon Two-sample Test are shown. Dots indicate individual measures.

\section{Discussion}

Here, we have shown that the Tat protein of HIV is efficiently taken up by cytokineactivated endothelial cells, as previously observed with dendritic cells [37,38]. In particular, unlike the uptake occurring in the micromolar range, the entry of Tat at nano-micromolar concentrations into endothelial cells occurs only upon their activation by inflammatory cytokines, requires a biologically active protein, and it is hampered at $4{ }^{\circ} \mathrm{C}$. These findings suggest that the entry of low amounts $(1-100 \mathrm{ng} / \mathrm{mL})$ of Tat into IC-HUVEC is a conformation- and energy-dependent process, which is likely to be mediated by specific cell surface receptors activated by inflammatory mediators. Consistently, the prior incubation of IC-HUVEC with fibronectin or vitronectin, the Tat RGD peptide, or with $\alpha 5 \beta 1$, $\alpha v \beta 3$, or $\alpha \mathrm{v} \beta 5$ antagonists significantly reduces the entry of Tat. The blocking of both $\alpha 5 \beta 1$ and $\alpha \mathrm{v} \beta 3$ has additive inhibitory effects, and the entry of micromolar Tat concentrations $(1 \mu \mathrm{g} / \mathrm{mL})$ is almost completely abolished when cells are pre-incubated with a cocktail of mAbs directed against $\alpha 5 \beta 1, \alpha \mathrm{v} \beta 3$, and $\alpha \mathrm{v} \beta 5$ integrins, which is in agreement with the reported "cross-talk" occurring among these integrins. These results indicate that $\alpha 5 \beta 1, \alpha v \beta 3$, and $\alpha v \beta 5$ integrins are the main receptors responsible for the entry of Tat in IC-activated HUVEC, which is consistent with the ability of these integrins to mediate the cellular uptake of RGD-containing molecules [63-67]. 
IC-HUVEC take up Tat very quickly (after just $5 \mathrm{~min}$ ). This does not occur in nonactivated HUVEC. The timing of Tat entry into the IC-HUVEC is identical to that previously observed in dendritic cells [37]. In other cell types such as, for example, epithelial cells, the uptake of Tat takes longer [68]. This difference correlates with the different mechanisms underlying the two types of Tat uptake. In fact, Tat entry into epithelial cells requires high (micromolar) amounts of the protein and is mediated by the interaction between its basic residues and the HSPGs of the cell membrane [68]; in contrast, the entry of Tat into dendritic cells and cytokine-activated endothelial cells occurs at lower concentrations of the protein (1-100 $\mathrm{ng} / \mathrm{mL}$ ) and is mediated by RGD-binding integrins.

In this regard, it is noteworthy that inflammatory cytokine-activated endothelial cells display antigen processing and presentation capabilities, which are typical features of dendritic cells [69]. Relationships between these two cell types go further, as dendritic cells may acquire an endothelial cell phenotype under specific stimuli, [70] and monocytes may differentiate in both dendritic and endothelial cell types [71,72].

In this context, we found that inflammatory cytokines increased the expression of the $\alpha \mathrm{v} \beta 5$ but not the $\alpha 5 \beta 1$ and $\alpha \mathrm{v} \beta 3$ integrins on endothelial cell surface; however, inflammatory cytokines augmented endothelial cell adhesion onto fibronectin and vitronectin, which are the natural ligands of these receptors. Specifically, the ratio of IC-HUVEC to HUVEC adhesion to fibronectin coated at $0.1,1$, and $10 \mu \mathrm{g} / \mathrm{mL}$ was $1.67,1.33$, and 1.14 , respectively. Similarly, the ratio of IC-HUVEC to HUVEC adhesion to vitronectin coated at $0.1,1$, and $10 \mu \mathrm{g} / \mathrm{mL}$ was 2.0,1.5, and 1.33, respectively. Altogether, these data indicate that under our experimental conditions, inflammatory cytokines enhance the function of RGD-binding integrins.

The results of modeling-docking calculations, which have been strengthened by blocking experiments of Tat uptake with mAbs directed against the single $\alpha \mathrm{v}$ chain as compared to mAbs binding the $\alpha v \beta 3$ heterodimer, indicate that Tat and the $\alpha v \beta 3$ integrin form a stable complex where the RGD region of Tat contacts both chains, as known for the structure of the integrin in complex with a cyclic RGD peptide. Additional extensive interactions are predicted to occur in this structure model between the $\mathrm{C}$-terminal region of Tat and both integrin subunits, whereas the Tat basic sequence does not appear to interact with $\alpha v \beta 3$. These data further support the conclusion that the basic region of Tat is not directly involved in binding to this integrin. Accordingly, Tat can concomitantly bind integrins with the RGD domain and HSPG with its basic region. However, our data indicate that Tat enters IC-HUVEC via RGD binding integrins at low $(1-100 \mathrm{ng} / \mathrm{mL})$ concentrations, whereas at higher concentrations $(1 \mu \mathrm{g} / \mathrm{mL})$, Tat binds HSPG and possibly enters cells via an integrin-independent pathway, as entry is only partially blocked by competition with a Tat-RGD peptide. Intriguingly, the blockade is complete when mAbs against the three RGD-binding integrins are used, suggesting some level of cooperation/interference between the two pathways at high Tat concentrations. Alternatively, differences between $\mathrm{mAbs}$ and Tat peptides with regard to steric hindrance and affinity for their ligands should be considered.

These findings are of relevance, as endothelial cells have been reported to be highly dysfunctional or injured in HIV infection [24,73-75]. This is consistent with the known role of inflammatory cytokines, which are markedly elevated in HIV-infected individuals, in inducing endothelial cell activation and dysfunction [17-22,76-78]. Of note, activated and dysfunctional endothelial cells become the target of Tat that, in turn, further alters their functionality. In fact, in the pre-ART era Tat has been the first HIV-1 protein reported to severely affect endothelial cells, promoting vascular endothelia dysfunction and the onset and progression of the angioproliferative KS [40,79]. More recently, a role for Tat in promoting the occurrence of cardiovascular diseases, whose prevalence is greatly increased even in successfully ART-treated individuals, has also been proposed [80]. This is consistent with the persistent inflammation and immune activation during suppressive antiretroviral therapy, which maintain endothelial cells dysfunctional and responsive to Tat that continues to be expressed despite virus suppression, as evidenced by seroconversion for anti-Tat 
antibodies in treated patients [80,81]. As inflammatory cytokines are strong inducers of endothelial cell activation and dysfunction, this evidence indicates a role for extracellular Tat in the pathogenesis of HIV comorbidities (AIDS-associated and non-AIDS related) that goes beyond its role in the virus life cycle and is characterized by the many ways extracellular Tat affects the physiology of the vascular system, contributing to the onset of endothelial cell dysfunction and progression toward virtually all HIV-related comorbidities.

Here, we also show that the addition of soluble, biologically active Tat to dysfunctional endothelial cells (i.e., pre-activated by TNF- $\alpha$, IL- $1 \beta$, and IFN- $\gamma$ ), and exposed to cell-free HIV-1 efficiently promotes productive HIV infection. In these experiments, different concentrations of Tat protein were used; however, the dose of Tat $10 \mu \mathrm{g} / \mathrm{mL}$ gave the most consistent results, as compared to lower Tat concentrations.

Several and non-mutually exclusive reasons may account for this. In particular, the intracellular availability of biologically active Tat in the infection experiments is critical, as the transactivating activity of Tat is an absolute requirement for HIV gene expression and replication. In fact, no productive infection occurs when the mutated, transactivation silent $\mathrm{Tat}_{\text {cys22 }}$ protein is used in place of wild-type, transcriptionally active Tat. However, in our in vitro model, the intracellular levels of biologically active Tat may be reduced due to Tat stickiness to the cell membrane or extracellular matrix [39]. Furthermore, as for dendritic cells, also cytokine-activated endothelial cells rapidly digest internalized proteins [82-85]. In accordance with this, we have found that intracellular Tat levels begin to drop $30 \mathrm{~min}$ after entry in IC-HUVEC (Figure S1), as previously observed for dendritic cells [37].

On the other hand, the amounts of Tat $(1-500 \mathrm{ng} / \mathrm{mL})$ detected in the sera of HIVinfected individuals [51-53] are likely to be much lower than those present in the tissues where the virus resides. In fact, immediately after its release by acutely infected leukocytes, Tat binds the extracellular matrix $[39,44]$, increasing leukocyte adhesiveness to endothelial cells [50], thereby placing HIV-infected, Tat-releasing leukocytes in close proximity with endothelial cells. Accordingly, Tat concentrations in solid tissues are higher than those used in our experimental model.

Although Tat can upregulate the expression of HIV co-receptors [52], no productive infection occurs when the mutated Tat ${ }_{\text {cys22 }}$ protein (which is devoid of transactivating capacity) is used in place of wild-type, transcriptionally active Tat. In addition, kinetics of endothelial cell infection demonstrates that the percentage of p24-positive IC-HUVEC increases over time. Furthermore, the HIV-reverse transcriptase inhibitor Efavirenz strongly reduces Tat-induced HIV infection of IC-HUVEC. Altogether, these results indicate that Tat directly induces productive HIV infection in IC-HUVEC. As most of the Tat protein produced during virus replication is released extracellularly, HIV-1 infected endothelial cells may represent a new source of Tat, which may maintain and fuel HIV infection, the endothelial cell dysfunction, as well as the dysregulation of the immune system and central nervous system, even in individuals on effective cART. Of importance, the tight interactions between endothelial cells and transmigrating mononuclear cells suggest that extracellular Tat may sustain cell-to-cell HIV transmission at the time of lymphocytes and monocytes extravasation, particularly in an inflammatory environment, thus fuelling infection and/or virus reactivation in latently infected cells. Of importance, HIV-1 infected endothelial cells are hardly attackable by antiretroviral drugs, as the tight cell-to-cell contacts occurring during the trans-endothelial migration of leukocytes are likely to strongly facilitate virus transmission while limiting ART efficacy [86].

As endothelial cells are among the most represented cell type in the body, their contribution to HIV dissemination and reservoir formation and maintenance is probably very relevant. Indeed, activated monocytes and lymphocytes have been observed to accumulate in multiple perivascular foci distributed at random in the vasculature, which was reported in the pre-ART era, suggesting the potential contribution of endothelial cells to HIV dissemination in the primary infection and maintenance in the chronic phase of infection [87-89]. This may help explain the difficulties in achieving a functional cure and in advancing toward eradication, even in individuals treated very early after HIV acquisition. 
Intriguingly, naturally occurring anti-Tat Abs have been shown to delay or block progression to disease, and those induced by Tat vaccination of individuals on effective ART appear to promote the restoration of immune homeostasis in ART-treated subjects and to exert an effective antiviral response at the portal of entry in vivo in non-human primates (reviewed in [90-93]). Taken together, these published evidence and the present findings indicate that Tat represents a major virulence factor, driving HIV replication and dissemination, inducing dysregulation of the immune, vascular, and central nervous systems, and eventually leading to the occurrence of severe comorbidities despite suppressive therapy.

\section{Materials and Methods}

\subsection{Tat Protein Production and Purification}

The HIV-1 Tat protein and the mutated, transactivation silent, Tat ${ }_{\text {cys } 22}$ protein from human T lymphotropic virus type IIIB-BH-10 (subtype B) were expressed in Escherichia coli, purified to homogeneity by heparin affinity chromatography and reverse HPLC, and handled as described previously $[34,37,40,57]$. Three different Tat preparations were used with reproducible results. In all lots, endotoxin concentration was below the detection limit $(<0.02 \mathrm{EU} / \mu \mathrm{g})$, as determined by the Lymulus Amoebocyte Lysate analysis (Pyrochrome, Associates of Cape Cod, Falmouth, MA, USA). The purified Tat protein was fully biologically active, as tested by the rescue assay on HLM-1 cells carrying a Tat-defective HIV provirus [86], and by monocyte-derived dendritic cell uptake [37]. In some experiments, the recombinant Tat protein was inactivated by exposing it to air and light for $18 \mathrm{~h}$ at room temperature $[40,94]$. Oxidized Tat changed its conformation and underwent multimerization, as revealed by SDS-PAGE and analysis of its elution profile by HPLC [38,95]. Oxidized Tat was no longer capable of promoting the replication of Tat-defective proviruses, as determined by the HLM- 1 assay $[38,40]$. Tat ${ }_{\text {cys } 22}$ is a clade B Tat protein carrying a cysteine to glycine substitution at position 22 ( Tat $_{\text {cys22 }}$ ), which renders the protein transactivationsilent [96], and it incapable of inducing dendritic cell maturation, although it is taken up by monocyte-derived dendritic cells as well as wild-type Tat $[37,97]$, indicating retention of the conformational features required for binding to HSPG and/or to RGD-binding integrins and cell entry.

\subsection{Reagents}

Gelatin (denatured collagen I, from bovine skin), vitronectin (from human plasma), bovine serum albumin (BSA, fraction V) and Efavirenz were obtained from Sigma-Aldrich (Milan, Italy). Human recombinant IL- $1 \beta$, TNF- $\alpha$, and IFN- $\gamma$, and fibronectin from human plasma were purchased from Roche Molecular Biochemicals (Indianapolis, IN, USA). MAbs directed against the $\alpha 5 \beta 1, \alpha v \beta 3, \alpha v \beta 5$, or $\alpha 6 \beta 4$ integrins were obtained from ChemiconMerck-Millipore (Darmstadt, Germany). The anti-CD31 (PECAM-1) mAb was purchased from Santa Cruz Biotechnology (Dallas, TX, USA). The Tat peptides (11-25), (46-60), and (66-80) were from UFP Service, University of Ferrara, Italy. Phosphate-buffered saline (PBS) solution, cell growth medium (RPMI 1640) and media supplements were obtained from Invitrogen-Life Technologies (Milan, Italy). Fetal bovine serum (FBS) was from HyClone (Logan, UT, USA).

\subsection{Endothelial Cell Culture and Activation}

HUVEC were obtained from Lonza (Verviers, Belgium) and grown in RPMI 1640 containing 15\% FBS and supplemented with heparin, endothelial cell growth supplement, sodium pyruvate, and essential and non-essential amino acids (complete growth medium) (Invitrogen-Life Technologies, Milan, Italy). HUVEC activation was performed by culturing the cells for a total of 5 days ( 3 days in complete growth medium and 2 days in RPMI- $15 \%$ FBS) in the presence of human recombinant IFN- $\gamma$, IL- $1 \beta$, and TNF- $\alpha$, combined together at concentrations ( $10 \mathrm{U} / \mathrm{mL}, 5 \mathrm{ng} / \mathrm{mL}$, and $2 \mathrm{ng} / \mathrm{mL}$, respectively) comparable to those found in conditioned media from activated or transformed leukocytes [40]. HUVEC activation by inflammatory cytokines was revealed by the induction of expression of cell surface ICAM-1 
(CD54), as determined in flow cytometry upon staining with a fluorochrome-conjugated $\mathrm{mAb}$ directed against CD54 (Immunotech, Marseille, France).

\subsection{Evaluation of Tat Protein Cellular Uptake by Flow Cytometry}

Cytokine-activated or non-activated HUVEC were suspended via the use of Cell Dissociation Solution Non-enzymatic 1x (Sigma-Aldrich, Milan, Italy) and incubated for 5,10 , or $30 \mathrm{~min}$ at $37^{\circ} \mathrm{C}$ (or at $4{ }^{\circ} \mathrm{C}$ for endocytosis-blocking experiments), in the dark, in RPMI $1640-15 \%$ FBS containing serial dilution of Tat or its suspension buffer (PBS- $0.1 \%$ BSA). For blocking experiments, prior to their exposure to Tat or control buffer, cells were incubated upon continuous gentle shaking for $2 \mathrm{~h}$ at $4{ }^{\circ} \mathrm{C}$ with Tat peptides, fibronectin, vitronectin, or with $\mathrm{mAb}$ directed against $\alpha 5 \beta 1, \alpha v \beta 3, \alpha v \beta 5, \alpha 6 \beta 4$, or CD31. Incubation with the peptides, fibronectin, vitronectin, or $\mathrm{mAb}$ dilution buffer (PBS- $0.1 \% \mathrm{BSA}$ ) was employed as a control. The mAbs were used at a final concentration of $5 \mu \mathrm{g} / \mathrm{mL}$ each. The Tat peptides were employed at $100 \mu \mathrm{g} / \mathrm{mL}$ each, while fibronectin and vitronectin were combined at $50 \mu \mathrm{g} / \mathrm{mL}$ each.

After their exposure to Tat or control buffer, cells were washed with cold medium and treated for $10 \mathrm{~min}$ at $37{ }^{\circ} \mathrm{C}$ with $0.05 \%$ trypsin to remove any externally bound protein. After fixation and permeabilization, cells were stained with affinity-purified rabbit polyclonal anti-Tat immunoglobulin $\mathrm{G}$ (IgG) Ab [37,97], or rabbit IgG control Ab (ICN Biomedicals, Opera, Italy), followed by fluorescein-isothiocyanate (FITC)-conjugated anti-rabbit Ig (Pierce, Rockford, IL, USA). Fluorescence was analyzed by flow cytometry, and results were expressed as the percentage of positive cells as compared with isotypestained samples [37,97]. To demonstrate the specific intracellular localization of the protein, staining with anti-Tat Ab was always performed also with non-permeabilized cells.

\subsection{Confocal Microscopy}

To determine whether Tat enters adherent IC-HUVEC, the same short-term endocytosis pulse-chase assay previously developed to visualize the internalization of RGDcontaining extracellular matrix molecules was utilized [98]. Specifically, Tat protein was labeled with rhodamine at lysine residues as described [55]. To ensure that biological activity was maintained, rhodamine-labeled Tat was tested for its capability of promoting vascular cell growth [34]. Then, IC-HUVEC were incubated at $4{ }^{\circ} \mathrm{C}$ in RPMI- $15 \%$ FBS containing $100 \mathrm{ng} / \mathrm{mL}$ of rhodamine labeled-Tat (pulse phase). After $60 \mathrm{~min}$ of incubation, cells were washed and then incubated at $37^{\circ} \mathrm{C}$ in RPMI- $15 \%$ FBS in the absence of labeled Tat (chase phase). After $30 \mathrm{~min}$, cells were washed, fixed with $4 \%$ paraformaldehyde, permeabilized in PBS-0.3\% Triton X-100 (Sigma-Aldrich), and then observed and photographed at the confocal microscope, as described [98].

Images were taken on an inverted microscope (Olympus, Tokyo, Japan) equipped with a confocal spectral imaging system (Olympus Fluoview 1000) using a (Olympus) planapo objective $60 \times$ oil A.N. 1.42. Excitation light was obtained by a Laser Dapi $408 \mathrm{~nm}$ for Dapi and Diode Laser HeNe $(561 \mathrm{~nm}$ ) for Tetramethylrhodamine (TRITC). Emitted fluorescence was recorded during single excitation sessions in the same field, and same conditions for stack images collection. DAPI emission was recorded from 415 to $485 \mathrm{~nm}$, TRITC emission was recorded from 568 to $678 \mathrm{~nm}$. Images recorded have an optical thickness of 0.40 micrometers. Merging was obtained by freeware software "ImageJ" (vers1.29) from $\mathrm{NIH}$, USA

\subsection{Docking Calculations of the Tat-Integrin Complex}

Docking calculations between integrin $\alpha \mathrm{v} \beta 3$ and Tat $\mathrm{BH} 10$ were performed with the program HADDOCK2.2 [99], where the docking process is driven by distance restraints between residues that are involved in the intermolecular interaction (http:/ / www.nmr. chem.uu.nl/haddock). The structures of both proteins in the complex are also required as input. The input structure of integrin $\alpha \mathrm{v} \beta 3$ was taken from the PDB [62] (PDB identifier: 1L5G) [61]. For Tat BH10, three different input structures were used, which were generated 
by homology modeling with the program MODELLER9.17 [100]. The templates for the modeling were also taken from the PDB [PDB identifiers: 1JFW [101,102], and 1TBC (unpublished)]. These structures of the Tat protein are from different subtypes of the HIV-1 virus, and they were all used because despite their high sequence identity (average:

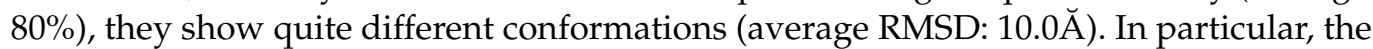
RGD segment is solvent exposed (accessibility: $\approx 40 \%$ ) in only one of the three structures, whereas in the other two, only Arg78 is partially solvent exposed, while Gly79 and Asp80 are largely buried (accessibility: $\approx 10 \%$ ).

The distance restraints used in the HADDOCK calculations were generated as described in the HADDOCK protocol [99], by defining the residues at the interface for each of the two proteins in the complex (Table 1). The residues were chosen based on the available structure of the complex between integrin and a cyclic peptide that contains the RGD sequence [61], filtering out residues with solvent accessibility lower than $50 \%$. Solvent accessibility was calculated with the program NACCESS [103].

The solutions of the docking calculations were clustered, using a threshold value of $1.5 \AA$ for the pairwise backbone root-mean-square deviation (RMSD) at the interaction surface, and the resulting clusters were ranked according to their average interaction energy (defined as the sum of van der Waals, electrostatic energy terms) and buried surface area.

\subsection{Infection Experiments}

For the infection experiments NL4.3, an X4-tropic HIV clade B lab strain grown in Jurkat cell line was used. On day 0, IC-HUVEC or control HUVEC $\left(1 \times 10^{5} / \mathrm{mL}\right.$, resuspended in RPMI $164015 \%$ FBS and basic fibroblast growth factor at $10 \mathrm{ng} / \mathrm{mL}$ ) were dispensed in 6-wells plates (COSTAR), pre-coated with gelatin $(1.5 \%)$, and incubated at $37^{\circ} \mathrm{C}, 5 \% \mathrm{CO}_{2}$, $90 \%$ humidity. The following day, the RPMI 1640 15\% FBS was replaced and combined IL-1 $\beta, \mathrm{TNF} \alpha$, and IFN $\gamma$ were added to the cells. The next day, IC-HUVEC were exposed contemporarily to NL4.3, (p24-Gag $=70 \mathrm{ng} / \mathrm{mL}), \pm$ Tat protein $(1 \mu \mathrm{M}, 10 \mu \mathrm{g} / \mathrm{mL})$, in a final volume of $1.2 \mathrm{~mL}$. Four days later, cells were washed, trypsinized to detach them and to remove both the Tat protein and the virions bound to the cell membrane, permeabilized, and stained for intracellular p24-Gag protein (see below). In some experiments, a proportion of the detached IC-HUVEC was reseeded and cultured for an additional 4 days in RPMI-15\% FBS. After that, cells underwent the same procedure to evaluate infection at day 8 post-infection. In blocking experiments, IC-HUVECs were pretreated for $1 \mathrm{~h}$ at $37^{\circ} \mathrm{C}$ with Efavirenz ( $500 \mathrm{nM}$ ) or its resuspension buffer (DMSO, $0.005 \%$ ) prior to virus exposure, and analyzed 4 days post-infection for intracellular p24-Gag protein.

For intracellular p24-Gag staining, cells were transferred to V-bottomed tubes and washed once in PBS containing 2.5\% FCS. Then, cells were fixed and permeabilized using the Cytofix/Cytoperm Kit (BD-PharMingen, San Diego, CA, USA). Permeabilized cells were washed using the wash buffer provided by the manufacturer and resuspended for $60 \mathrm{~min}$ at $4{ }^{\circ} \mathrm{C}$ with $50 \mu \mathrm{L}$ of a 1:50 dilution of a phycoerythrin (PE)-conjugated mouse anti-p24-Gag mAb (KC57-RD1; Beckman Coulter, Inc., Fullerton, CA, USA) or a mouse IgG1 isotypic control antibody. After two additional washes, cells were analyzed with a FACSCanto flow cytometer (Becton Dickinson), and data analysis was performed with FACSDiva software (Becton Dickinson).

Live cells initially gated by forward and side scatter were analyzed for the intracellular expression of p24-Gag. The number of p24-Gag-positive cells was determined using a bivariate plot of fluorescence versus side scatter, the gate was set on mock-p24-Gag positive cells.

\subsection{Statistical Analysis}

A Wilcoxon Two-sample Test was used. Statistical analyses were carried out at onesided with a 0.05 significance level, using SAS ${ }^{\circledR}$ (Version 9.4, SAS Institute Inc., Cary, NC, USA). 
Supplementary Materials: The following are available online at https:/ /www.mdpi.com/1422-0 067/22/1/317/s1, Figure S1: Extracellular Tat protein uptake by activated endothelial cells after $30 \mathrm{~min}$ exposure. HUVEC (blue plots) or IC-HUVEC (red plots) were incubated for $30 \mathrm{~min}$ in medium containing serial concentrations $(1-1000 \mathrm{ng} / \mathrm{mL})$ of biologically active Tat or its suspension buffer (PBS-0.1\% BSA). The intracellular Tat content was evaluated by flow cytometry after staining with affinity-purified rabbit anti-Tat polyclonal Ab (orisotype control), as described in Section 4 Materials and Methods. Non-permeabilized cells were also analyzed by intracellular staining and flow cytometry, with negative results. Results are expressed as the percentage of positive cells, as compared to isotype-stained samples. Box-plot of data obtained from three independent experiments and analyzed by the Mann-Whitney nonparametric test are shown. Figure S2: Extracellular Tat protein is efficiently taken up by activated endothelial cells. Images of serial sections of the cell analyzed in Figure 1B,C showing the presence of Tat (red) in the optical sections of the central region of the cell.

Author Contributions: Conceptualization, A.C., G.B. and B.E.; methodology, A.C., G.B. and B.E.; software, C.A. and L.B.; formal analysis and data curation, O.P., C.P., G.B. and A.C.; investigation, C.P., S.M., A.T., M.R.P.C., A.A., M.C., M.F., C.S., C.A., L.B. and G.B.; writing-original draft preparation, G.B., C.S. and B.E.; writing-review and editing, A.C., G.B., P.M. and B.E.; visualization, A.T., G.B., and O.P.; supervision, A.T., A.C., G.B. and B.E.; funding acquisition, A.C., P.M. and B.E. All authors have read and agreed to the published version of the manuscript.

Funding: This work was supported by the Italian Ministry of Health, grant RF-2011-02348970 (C.A.), grant RF-2016-02364744 (M.P.), and Ricerca Corrente 2019 and 2020 (B.E.).

Institutional Review Board Statement: Not Applicable.

Informed Consent Statement: Not applicable.

Data Availability Statement: The data presented in this study are available on request from the corresponding author.

Acknowledgments: The authors wish to thank Emanuele Fanales-Belasio, André Iovane, Elena Toschi, Filomena Nappi, Patrizia Leone, for assistance in initial experiments; Francesca Cammisa, Stefania De Menna, Silvia Tobelli and Flavia Fedeli for the excellent editorial and administrative assistance. Ferdinando Costa, Patrizia Cocco and Pietro Arciero for technical support.

Conflicts of Interest: The authors declare no conflict of interest.

$\begin{array}{ll}\begin{array}{l}\text { Abbreviations } \\ \text { HIV-1 }\end{array} & \begin{array}{l}\text { Human Immunodeficiency Virus 1 } \\ \text { human umbilical vein endothelial cells } \\ \text { arginine-glycine-aspartic acid domain } \\ \text { HUVEC }\end{array} \\ \text { RGD } & \text { hembination antiretroviral therapy } \\ \text { cART } & \text { interleukin 1 } \\ \text { HSPG } & \text { tumor necrosis factor } \\ \text { IL-1 } & \text { interferon } \\ \text { TNF } & \text { intercellular adhesion molecule-1 } \\ \text { IFN } & \text { inflammatory cytokines activated HUVEC } \\ \text { ICAM-1 } & \text { dimethyl sulfoxide } \\ \text { IC-HUVEC } & \text { phosphate-buffered saline }\end{array}$

\section{References}

1. Guerrero, P.A.; McCarty, J.H. Integrins in vascular development and pathology. Adv. Pharmacol. 2018, 81, 129-153. [CrossRef] [PubMed]

2. Rocha, L.A.; Learmonth, D.A.; Sousa, R.A.; Salgado, A.J. $\alpha \mathrm{v} \beta 3$ and $\alpha 5 \beta 1$ integrin-specific ligands: From tumor angiogenesis inhibitors to vascularization promoters in regenerative medicine? Biotechnol. Adv. 2018, 36, 208-227. [CrossRef] [PubMed]

3. Shafiei, M.S.; Lui, S.; Rockey, D.C. Integrin-linked kinase regulates endothelial cell nitric oxide synthase expression in hepatic sinusoidal endothelial cells. Liver Int. 2015, 35, 1213-1221. [CrossRef] [PubMed]

4. Chen, X.; Lin, J.; Hu, T.; Ren, Z.; Li, L.; Hameed, I.; Zhang, X.; Men, C.; Guo, Y.; Xu, D.; et al. Galectin-3 exacerbates ox-LDLmediated endothelial injury by inducing inflammation via integrin $\beta 1$-RhoA-JNK signaling activation. J. Cell. Physiol. 2019, 234, 10990-11000. [CrossRef] [PubMed] 
5. Chen, C.; Li, R.; Ross, R.S.; Manso, A.M. Integrins and integrin-related proteins in cardiac fibrosis. J. Mol. Cell. Cardiol. 2016, 93, 162-174. [CrossRef]

6. Finney, A.C.; Stokes, K.Y.; Pattillo, C.B.; Orr, A.W. Integrin signaling in atherosclerosis. Cell. Mol. Life Sci. 2017, 74, 2263-2282. [CrossRef]

7. Edwards, D.N.; Bix, G.J. Roles of blood-brain barrier integrins and extracellular matrix in stroke. Am. J. Physiol. Cell Physiol. 2019, 316, C252-C263. [CrossRef]

8. Labus, J.; Wöltje, K.; Stolte, K.N.; Häckel, S.; Kim, K.S.; Hildmann, A.; Danker, K. IL-1 $\beta$ promotes transendothelial migration of PBMCs by upregulation of the FN/ $\alpha 5 \beta 1$ signalling pathway in immortalised human brain microvascular endothelial cells. Exp. Cell Res. 2018, 373, 99-111. [CrossRef]

9. Natarajan, M.; Udden, M.M.; McIntire, L.V. Adhesion of sickle red blood cells and damage to interleukin-1 beta stimulated endothelial cells under flow in vitro. Blood 1996, 87, 4845-4852. [CrossRef] [PubMed]

10. Sun, W.Y.; Pitson, S.M.; Bonder, C.S. Tumor necrosis factor-induced neutrophil adhesion occurs via sphingosine kinase-1dependent activation of endothelial $\alpha 5 \beta 1$ integrin. Am. J. Pathol. 2010, 177, 436-446. [CrossRef]

11. Danese, S.; Sans, M.; de la Motte, C.; Graziani, C.; West, G.; Phillips, M.H.; Pola, R.; Rutella, S.; Willis, J.; Gasbarrini, A.; et al. Angiogenesis as a novel component of inflammatory bowel disease pathogenesis. Gastroenterology 2006, 130, 2060-2073. [CrossRef] [PubMed]

12. Barillari, G.; Albonici, L.; Incerpi, S.; Bogetto, L.; Pistritto, G.; Volpi, A.; Ensoli, B.; Manzari, V. Inflammatory cytokines stimulate vascular smooth muscle cells locomotion and growth by enhancing alpha5beta1 integrin expression and function. Atherosclerosis 2001, 154, 377-385. [CrossRef]

13. Zicari, S.; Sessa, L.; Cotugno, N.; Ruggiero, A.; Morrocchi, E.; Concato, C.; Rocca, S.; Zangari, P.; Manno, E.C.; Palma, P. Immune activation, inflammation, and non-AIDS co-morbidities in HIV-infected patients under long-term ART. Viruses 2019, 11, 200. [CrossRef] [PubMed]

14. Dinh, D.M.; Volpe, G.E.; Duffalo, C.; Bhalchandra, S.; Tai, A.K.; Kane, A.V.; Wanke, C.A.; Ward, H.D. Intestinal microbiota, microbial translocation, and systemic inflammation in chronic HIV infection. J. Infect. Dis. 2015, 211, 19-27. [CrossRef] [PubMed]

15. Sachdeva, N.; Yoon, H.S.; Oshima, K.; Garcia, D.; Goodkin, K.; Asthana, D. Biochip array-based analysis of plasma cytokines in HIV patients with immunological and virological discordance. Scand. J. Immunol. 2007, 65, 549-554. [CrossRef] [PubMed]

16. Sadeghi, M.; Süsal, C.; Daniel, V.; Naujokat, C.; Zimmermann, R.; Huth-Kühne, A.; Opelz, G. Short communication: Decreasing soluble CD30 and increasing IFN-gamma plasma levels are indicators of effective highly active antiretroviral therapy. AIDS Res. Hum. Retrovir. 2007, 23, 886-890. [CrossRef] [PubMed]

17. López, M.; San Román, J.; Estrada, V.; Vispo, E.; Blanco, F.; Soriano, V. Endothelial dysfunction in HIV infection-The role of circulating endothelial cells, microparticles, endothelial progenitor cells and macrophages. AIDS Rev. 2012, 14, 223-230. [PubMed]

18. Marincowitz, C.; Genis, A.; Goswami, N.; De Boever, P.; Nawrot, T.S.; Strijdom, H. Vascular endothelial dysfunction in the wake of HIV and ART. FEBS J. 2019, 286, 1256-1270. [CrossRef]

19. Shah, A.S.V.; Stelzle, D.; Lee, K.K.; Beck, E.J.; Alam, S.; Clifford, S.; Longenecker, C.T.; Strachan, F.; Bagchi, S.; Whiteley, W.; et al. Global Burden of Atherosclerotic Cardiovascular Disease in People Living With HIV. Circulation 2018, 138, 1100-1112. [CrossRef]

20. Bush, K.N.V.; Teel, J.L.; Watts, J.A.; Gore, R.S.; Alvarado, G.; Harper, N.L.; Okulicz, J.F. Association of Endothelial Dysfunction and Antiretroviral Therapy in Early HIV Infection. JAMA Netw. Open 2019, 2, e1913615. [CrossRef]

21. Rajendran, P.; Rengarajan, T.; Thangavel, J.; Nishigaki, Y.; Sakthisekaran, D.; Sethi, G.; Nishigaki, I. The vascular endothelium and human diseases. Int. J. Biol. Sci. 2013, 9, 1057-1069. [CrossRef]

22. Toborek, M.; Lee, Y.W.; Flora, G.; Pu, H.; Andras, I.E.; Wylegala, E.; Hennig, B.; Nath, A. Mechanisms of the blood-brain barrier disruption in HIV-1 infection. Cell. Mol. Neurobiol. 2005, 25, 181-199. [CrossRef] [PubMed]

23. Wu, Y.; Marsh, J.W. Selective transcription and modulation of resting T cell activity by preintegrated HIV DNA. Science 2001, 293, 1503-1506. [CrossRef]

24. Chi, D.; Henry, J.; Kelley, J.; Thorpe, R.; Smith, J.K.; Krishnaswamy, G. The effects of HIV infection on endothelial function. Endothelium 2000, 7, 223-242. [CrossRef] [PubMed]

25. Matzen, K.; Dirkx, A.E.; oude Egbrink, M.G.; Speth, C.; Gotte, M.; Ascherl, G.; Grimm, T.; Griffioen, A.W.; Sturzl, M. HIV-1 Tat increases the adhesion of monocytes and T-cells to the endothelium in vitro and in vivo: Implications for AIDS-associated vasculopathy. Virus Res. 2004, 104, 145-155. [CrossRef] [PubMed]

26. Fischer, M.; Joos, B.; Wong, J.K.; Ott, P.; Opravil, M.; Hirschel, B.; Weber, R.; Huldrych, F.G.; Swiss HIV Cohort Study. Attenuated and nonproductive viral transcription in the lymphatic tissue of HIV-1-infected patients receiving potent antiretroviral therapy. J. Infect. Dis. 2004, 189, 273-285. [CrossRef] [PubMed]

27. Ferdin, J.; Goričar, K.; Dolžan, V.; Plemenitaš, A.; Martin, J.N.; Peterlin, B.M.; Deeks, S.G.; Lenassi, M. Viral protein Nef is detected in plasma of half of HIV-infected adults with undetectable plasma HIV RNA. PLoS ONE 2018, 13, e0191613. [CrossRef] [PubMed]

28. Wang, T.; Yi, R.; Green, L.A.; Chelvanambi, S.; Seimetz, M.; Clauss, M. Increased cardiovascular disease risk in the HIV-positive population on ART: Potential role of HIV-Nef and Tat. Cardiovasc. Pathol. 2015, 24, 279-282. [CrossRef] [PubMed]

29. Hansen, L.; Parker, I.; Sutliff, R.L.; Platt, M.O.; Gleason, R.L. Endothelial dysfunction, arterial stiffening, and intima-media thickening in large arteries from HIV-1 transgenic mice. Ann. Biomed. Eng. 2013, 41, 682-693. [CrossRef] 
30. Kline, E.R.; Kleinhenz, D.J.; Liang, B.; Dikalov, S.; Guidot, D.M.; Hart, C.M.; Jones, D.P.; Sutliff, R.L. Vascular oxidative stress and nitric oxide depletion in HIV-1 transgenic rats are reversed by glutathione restoration. Am. J. Physiol. Heart Circ. Physiol. 2008, 294, 2792-2804. [CrossRef]

31. Bussolino, F.; Mitola, S.; Serini, G.; Barillari, G.; Ensoli, B. Interactions between endothelial cells and HIV-1. Int. J. Biochem. Cell Biol. 2001, 33, 371-390. [CrossRef]

32. Toschi, E.; Barillari, G.; Sgadari, C.; Bacigalupo, I.; Cereseto, A.; Carlei, D.; Palladino, C.; Zietz, C.; Leone, P.; Stürzl, M.; et al Activation of Matrix-Metalloproteinase-2 and Membrane-Type-1-Matrix-Metalloproteinase in Endothelial Cells and Induction of Vascular Permeability in vivo by the Human Immunodeficiency Virus-1 Tat protein and Basic Fibroblast Growth Factor. Mol. Biol. Cell 2001, 12, 2934-2946. [CrossRef] [PubMed]

33. Ensoli, B.; Buonaguro, L.; Barillari, G.; Fiorelli, V.; Gendelman, R.; Morgan, R.A.; Wingfield, P.; Gallo, R.C. Release, uptake, and effects of extracellular human immunodeficiency virus type 1 Tat protein on cell growth and viral transactivation. J. Virol. 1993, 67, 277-287. [CrossRef]

34. Chang, H.C.; Samaniego, F.; Nair, B.C.; Buonaguro, L.; Ensoli, B. HIV-1 Tat protein exits from cells via a leaderless secretory pathway and binds to extracellular matrix-associated heparan sulfate proteoglycans through its basic region. AIDS 1997, 11, 1421-1431. [CrossRef]

35. Rayne, F.; Debaisieux, S.; Yezid, H.; Lin, Y.L.; Mettling, C.; Konate, K.; Chazal, N.; Arold, S.T.; Pugnière, M.; Sanchez, F.; et al. Phosphatidylinositol-[4,5]-bisphosphate enables efficient secretion of HIV-1 Tat by infected T-cells. EMBO J. 2010, 29, 1348-1362. [CrossRef]

36. Zeitler, M.; Steringer, J.P.; Müller, H.M.; Mayer, M.P.; Nickel, W. HIV-Tat Protein Forms Phosphoinositide-dependent Membrane Pores Implicated in Unconventional Protein Secretion. J. Biol. Chem. 2015, 290, 21976-21984. [CrossRef] [PubMed]

37. Fanales-Belasio, E.; Moretti, S.; Nappi, F.; Barillari, G.; Micheletti, F.; Cafaro, A.; Ensoli, B. Native HIV-1 Tat protein targets monocyte-derived dendritic cells and enhances their maturation, function, and antigen-specific T cell responses. J. Immunol. 2002, 168, 197-206. [CrossRef] [PubMed]

38. Fanales-Belasio, E.; Moretti, S.; Fiorelli, V.; Tripiciano, A.; Cossut, M.R.P.; Scoglio, A.; Collacchi, B.; Nappi, F.; Macchia, I.; Bellino, S.; et al. HIV-1 Tat Addresses Dendritic Cells to Induce a Predominant Th1-Type Adaptive Immune Response That Appears Prevalent in the Asymptomatic Stage of Infection. J. Immunol. 2009, 182, 2888-2897. [CrossRef] [PubMed]

39. Barillari, G.; Ensoli, B. Angiogenic effects of extracellular human immunodeficiency virus type 1 Tat protein and its role in the pathogenesis of AIDS-associated Kaposi's sarcoma. Clin. Microbiol. Rev. 2002, 15, 310-326. [CrossRef]

40. Barillari, G.; Gendelman, R.; Gallo, R.C.; Ensoli, B. The Tat protein of human immunodeficiency virus type 1, a growth factor for AIDS Kaposi sarcoma and cytokine-activated vascular cells, induces adhesion of the same cell types by using integrin receptors recognizing the RGD amino acid sequence. Proc. Natl. Acad. Sci. USA 1993, 90, 7941-7945. [CrossRef]

41. Barillari, G.; Sgadari, C.; Palladino, C.; Gendelman, R.; Caputo, A.; Bohan Morris, C.; Nair, B.C.; Markham, P.; Nel, A.; Stürzl, M.; et al. Inflammatory cytokines synergize with the HIV-1 Tat protein to promote angiogenesis and Kaposi's sarcoma via induction of basic fibroblast growth factor and avb3 integrin. J. Immunol. 1999, 163, 1929-1935. [PubMed]

42. Samaniego, F.; Markham, P.D.; Gendelman, R.; Gallo, R.C.; Ensoli, B. Inflammatory cytokines induce endothelial cells to produce and release basic fibroblast growth factor and to promote Kaposi's sarcoma-like lesions in nude mice. J. Immunol. 1997, 158, 1887-1894. [PubMed]

43. Dandachi, D.; Morón, F. Effects of HIV on the Tumor Microenvironment. Adv. Exp. Med. Biol. 2020, 1263, 45-54. [CrossRef] [PubMed]

44. Ensoli, B.; Gendelman, R.; Markham, P.; Fiorelli, V.; Colombini, S.; Raffeld, M.; Cafaro, A.; Chang, H.K.; Brady, J.N.; Gallo, R.C. Synergy between basic fibroblast growth factor and HIV-1 Tat protein in induction of Kaposi's sarcoma. Nature 1994, 371, 674-680. [CrossRef] [PubMed]

45. Buonaguro, L.; Buonaguro, F.M.; Giraldo, G.; Ensoli, B. The human immunodeficiency virus type 1 Tat protein transactivates tumor necrosis factor beta gene expression through a TAR-like structure. J. Virol. 1994, 68, 2677-2682. [CrossRef] [PubMed]

46. Ambrosino, C.; Ruocco, M.R.; Chen, X.; Mallardo, M.; Baudi, F.; Trematerra, S.; Quinto, I.; Venuta, S.; Scala, G. HIV-1 Tat induces the expression of the interleukin-6 (IL6) gene by binding to the IL6 leader RNA and by interacting with CAAT enhancer-binding protein beta (NF-IL6) transcription factors. J. Biol. Chem. 1997, 272, 14883-14892. [CrossRef] [PubMed]

47. Lafrenie, R.M.; Wahl, L.M.; Epstein, J.S.; Hewlett, I.K.; Yamada, K.M.; Dhawan, S. HIV-1-Tat modulates the function of monocytes and alters their interactions with microvessel endothelial cells. A mechanism of HIV pathogenesis. J. Immunol. 1996, 156, 1638-1645. [PubMed]

48. Lafrenie, R.M.; Wahl, L.M.; Epstein, J.S.; Hewlett, I.K.; Yamada, K.M.; Dhawan, S. HIV-1-Tat protein promotes chemotaxis and invasive behavior by monocytes. J. Immunol. 1996, 157, 974-977. [PubMed]

49. Lafrenie, R.M.; Wahl, L.M.; Epstein, J.S.; Yamada, K.M.; Dhawan, S. Activation of monocytes by HIV-Tat treatment is mediated by cytokine expression. J. Immunol. 1997, 159, 4077-4083. [PubMed]

50. Dhawan, S.; Puri, R.K.; Kumar, A.; Duplan, H.; Masson, J.M.; Aggarwal, B.B. Human immunodeficiency virus-1-tat protein induces the cell surface expression of endothelial leukocyte adhesion molecule-1, vascular cell adhesion molecule-1, and intercellular adhesion molecule-1 in human endothelial cells. Blood 1997, 90, 1535-1544. [PubMed]

51. Westendorp, M.O.; Frank, R.; Ochsenbauer, C.; Stricker, K.; Dhein, J.; Walczak, H.; Debatin, K.M.; Krammer, P.H. Sensitization of T cells to CD95-mediated apoptosis by HIV-1 Tat and gp120. Nature 1995, 375, 497-500. [CrossRef] [PubMed] 
52. Xiao, H.; Neuveut, C.; Tiffany, H.L.; Benkirane, M.; Rich, E.A.; Murphy, P.M.; Jeang, K.T. Selective CXCR4 antagonism by Tat: Implications for in vivo expansion of coreceptor use by HIV-1. Proc. Natl. Acad. Sci. USA 2000, 97, 11466-11471. [CrossRef]

53. Poggi, A.; Carosio, R.; Fenoglio, D.; Brenci, S.; Murdaca, G.; Setti, M.; Indiveri, F.; Scabini, S.; Ferrero, E.; Zocchi, M.R. Migration of V delta 1 and V delta $2 \mathrm{~T}$ cells in response to CXCR3 and CXCR4 ligands in healthy donors and HIV-1-infected patients: Competition by HIV-1 Tat. Blood 2004, 103, 2205-2213. [CrossRef] [PubMed]

54. Johnson, T.P.; Patel, K.; Johnson, K.R.; Maric, D.; Calabresi, P.A.; Hasbun, R.; Nath, A. Induction of IL-17 and nonclassical T-cell activation by HIV-Tat protein. Proc. Natl. Acad. Sci. USA 2013, 110, 13588-13593. [CrossRef] [PubMed]

55. Mann, D.A.; Frankel, A.D. Endocytosis and targeting of exogenous HIV-1 Tat protein. EMBO J. 1991, 10, 1733-1739, PMCID: PMC45284. [CrossRef] [PubMed]

56. Mitola, S.; Soldi, R.; Zanon, I.; Barra, L.; Gutierrez, M.I.; Berkhout, B.; Giacca, M.; Bussolino, F. Identification of specific molecular structures of human immunodeficiency virus type 1 Tat relevant for its biological effects on vascular endothelial cells. J. Virol. 2000, 74, 344-353. [CrossRef]

57. Barillari, G.; Sgadari, C.; Fiorelli, V.; Samaniego, F.; Colombini, S.; Manzari, V.; Modesti, A.; Nair, B.C.; Cafaro, A.; Stürzl, M.; et al. The Tat protein of human immunodeficiency virus type-1 promotes vascular cell growth and locomotion by engaging the a5b1 and avb3 integrins by mobilizing sequestered basic fibroblast growth factor. Blood 1999, 94, 663-672. [PubMed]

58. Vogel, B.E.; Lee, S.J.; Hildebrand, A.; Craig, W.; Pierschbacher, M.D.; Wong-Staal, F.; Ruoslahti, E. A novel integrin specificity exemplified by binding of the alpha v beta 5 integrin to the basic domain of the HIV Tat protein and vitronectin. J. Cell Biol. 1993, 121, 461-468. [CrossRef]

59. Mathias, P.; Galleno, M.; Nemerow, G.R. Interactions of soluble recombinant integrin alphav beta5 with human adenoviruses. J. Virol. 1998, 72, 8669-8675. [CrossRef]

60. Zhu, X.; Evans, J.P. Analysis of the roles of RGD-binding integrins, alpha(4)/alpha(9) integrins, alpha(6) integrins, and CD9 in the interaction of the fertilin beta (ADAM2) disintegrin domain with the mouse egg membrane. Biol. Reprod. 2002, 66, 1193-1202. [CrossRef]

61. Xiong, J.P.; Stehle, T.; Zhang, R.; Joachimiak, A.; Frech, M.; Goodman, S.L.; Arnaout, M.A. Crystal structure of the extracellular segment of integrin alpha Vbeta3 in complex with an Arg-Gly-Asp ligand. Science 2002, 296, 151-155. [CrossRef] [PubMed]

62. Rose, P.W.; Prlic, A.; Altunkaya, A.; Bi, C.; Bradley, A.R.; Christie, C.H.; Di Costanzo, L.; Duarte, J.M.; Dutta, S.; Feng, Z.; et al. The RCSB protein data bank: Integrative view of protein, gene and 3D structural information. Nucleic Acids Res. 2017, 45, 271-281. [CrossRef]

63. Hill, H.R.; Augustine, N.H.; Williams, P.A.; Brown, E.J.; Bohnsack, J.F. Mechanism of fibronectin enhancement of group B streptococcal phagocytosis by human neutrophils and culture-derived macrophages. Infect. Immun. 1993, 61, $2334-2339$. [CrossRef] [PubMed]

64. van Putten, J.P.; Duensing, T.D.; Cole, R.L. Entry of OpaA+ gonococci into HEp-2 cells requires concerted action of glycosaminoglycans, fibronectin and integrin receptors. Mol. Microbiol. 1998, 29, 369-379. [CrossRef]

65. Erbacher, P.; Remy, J.-S.; Behr, J.-P. Gene transfer with synthetic virus-like particles via the integrin-mediated endocytosis pathway. Gene Ther. 1999, 6, 138-145. [CrossRef]

66. Lord, R.; Parsons, M.; Kirby, I.; Beavil, A.; Hunt, J.; Sutton, B.; Santis, G. Analysis of the interaction between RGD-expressing adenovirus type 5 fiber knob domains and alphavbeta3 integrin reveals distinct binding profiles and intracellular trafficking J. Gen. Virol. 2006, 87, 2497-2505. [CrossRef]

67. Han, X.; Gong, F.; Chi, L.; Feng, C.; Sun, J.; Chen, Y.; Liu, J.; Shen, Y. Cancer-targeted and glutathione-responsive micellar carriers for controlled delivery of cabazitaxel. Nanotechnology 2019, 30, 055601. [CrossRef]

68. Argyris, E.G.; Kulkosky, J.; Meyer, M.E.; Xu, Y.; Mukhtar, M.; Pomerantz, R.J.; Williams, K.J. The perlecan heparan sulfate proteoglycan mediates cellular uptake of HIV-1 Tat through a pathway responsible for biological activity. Virology 2004, 330, 481-486. [CrossRef]

69. Shao, Y.; Saredy, J.; Yang, W.Y.; Sun, Y.; Lu, Y.; Saaoud, F.; Drummer, C.; Johnson, C.; Xu, K.; Jiang, X.; et al. Vascular Endothelial Cells and Innate Immunity. Arterioscler. Thromb. Vasc. Biol. 2020, 40, e138-e152. [CrossRef]

70. Fernandez Pujol, B.; Lucibello, F.C.; Zuzarte, M.; Lütjens, P.; Müller, R.; Havemann, K. Dendritic cells derived from peripheral monocytes express endothelial markers and in the presence of angiogenic growth factors differentiate into endothelial-like cells. Eur. J. Cell Biol. 2001, 80, 99-110. [CrossRef]

71. Guilliams, M.; Ginhoux, F.; Jakubzick, C.; Naik, S.H.; Onai, N.; Schraml, B.U.; Segura, E.; Tussiwand, R.; Yona, S. Dendritic cells, monocytes and macrophages: A unified nomenclature based on ontogeny. Nat. Rev. Immunol. 2014, 14, 571-578. [CrossRef] [PubMed]

72. Arderiu, G.; Espinosa, S.; Peña, E.; Crespo, J.; Aledo, R.; Bogdanov, V.Y.; Badimon, L. Tissue factor variants induce monocyte transformation and transdifferentiation into endothelial cell-like cells. J. Thromb. Haemost. 2017, 15, 1689-1703. [CrossRef] [PubMed]

73. Mazzuca, P.; Caruso, A.; Caccuri, F. HIV-1 infection, microenvironment and endothelial cell dysfunction. New Microbiol. 2016, 39, 163-173. [PubMed]

74. Wang, D.; Melancon, J.K.; Verbesey, J.; Hu, H.; Liu, C.; Aslam, S.; Young, M.; Wilcox, C.S. Microvascular Endothelial Dysfunction and Enhanced Thromboxane and Endothelial Contractility in Patients with HIV. J. AIDS Clin. Res. 2013, 4, 267. [CrossRef] [PubMed] 
75. Gresele, P.; Falcinelli, E.; Sebastiano, M.; Baldelli, F. Endothelial and platelet function alterations in HIV-infected patients. Thromb. Res. 2012, 129, 301-308. [CrossRef]

76. Kobayashi, S.; Hamamoto, Y.; Kobayashi, N.; Yamamoto, N. Serum level of TNF alpha in HIV-infected individuals. AIDS 1990, 4, 169-170. [PubMed]

77. Lähdevirta, J.; Maury, C.P.; Teppo, A.M.; Repo, H. Elevated levels of circulating cachectin/tumor necrosis factor in patients with acquired immunodeficiency syndrome. Am. J. Med. 1988, 85, 289-291. [CrossRef]

78. Pugliese, A.; Torre, D.; Saini, A.; Pagliano, G.; Gallo, G.; Pistono, P.G.; Paggi, G.C. Cytokine detection in HIV-1/HHV-8 co-infected subjects. Cell. Biochem. Funct. 2002, 20, 191-194. [CrossRef]

79. Anand, A.R.; Rachel, G.; Parthasarathy, D. HIV proteins and endothelial dysfunction: Implications in cardiovascular disease. Front. Cardiovasc. Med. 2018, 5, 185. [CrossRef]

80. Ensoli, B.; Bellino, S.; Tripiciano, A.; Longo, O.; Francavilla, A.; Marcotullio, S.; Cafaro, A.; Picconi, O.; Paniccia, G.; Scoglio, A.; et al. Tat Reduces Immune Activation and Loss of Regulatory T-Cells and Improves Immune Function in Subjects on HAART. PLoS ONE 2010, 5, e13540. [CrossRef]

81. Mediouni, S.; Darque, A.; Baillat, G.; Ravaux, I.; Dhiver, C.; Tissot-Dupont, H.; Mokhtari, M.; Moreau, H.; Tamalet, C.; Brunet, C.; et al. Antiretroviral therapy does not block the secretion of the human immunodeficiency virus Tat protein. Infect. Disord. Drug Targets 2012, 12, 81-86. [CrossRef] [PubMed]

82. Langner, J.; Riemann, D.; Machulla, H.K.G. Antigen Processing and Presentation by Vascular Endothelial Cells: Biochemical and Cell Physiological Preconditions. Endothelium 1995, 3, 141-150. [CrossRef]

83. Savage, C.O.; Brooks, C.J.; Harcourt, G.C.; Picard, J.K.; King, W.; Sansom, D.M.; Willcox, N. Human vascular endothelial cells process and present autoantigen to human T cell lines. Int. Immunol. 1995, 7, 471-479. [CrossRef] [PubMed]

84. Marelli-Berg, F.M.; Hargreaves, R.E.; Carmichael, P.; Dorling, A.; Lombardi, G.; Lechler, R.I. Major histocompatibility complex class II-expressing endothelial cells induce allospecific nonresponsiveness in naive T cells. J. Exp. Med. 1996, 183, 1603-1612. [CrossRef]

85. Pober, J.S.; Merola, J.; Liu, R.; Manes, T.D. Antigen Presentation by Vascular Cells. Front. Immunol. 2017, 8, 1907. [CrossRef]

86. Sigal, A.; Kim, J.T.; Balazs, A.B.; Dekel, E.; Mayo, A.; Milo, R.; Baltimore, D. Cell-to-cell spread of HIV permits ongoing replication despite antiretroviral therapy. Nature 2011, 477, 95-98. [CrossRef]

87. Baroldi, G.; Corallo, S.; Moroni, M.; Repossini, A.; Mutinelli, M.R.; Lazzarin, A.; Antonacci, C.M.; Cristina, S.; Negri, C. Focal lymphocytic myocarditis in acquired immunodeficiency syndrome (AIDS): A correlative morphologic and clinical study in 26 consecutive fatal cases. J. Am. Coll. Cardiol. 1988, 12, 463-469. [CrossRef]

88. Birdsall, H.H.; Porter, W.J.; Green, D.M.; Rubio, J.; Trial, J.; Rossen, R.D. Impact of fibronectin fragments on the transendothelial migration of HIV-infected leukocytes and the development of subendothelial foci of infectious leukocytes. J. Immunol. 2004, 173, 2746-2754. [CrossRef]

89. Kruize, Z.; Kootstra, N.A. The Role of Macrophages in HIV-1 Persistence and Pathogenesis. Front. Microbiol. 2019, 10, 2828. [CrossRef]

90. Cafaro, A.; Tripiciano, A.; Picconi, O.; Sgadari, C.; Moretti, S.; Buttò, S.; Monini, P.; Ensoli, B. Anti-Tat Immunity in HIV-1 Infection: Effects of Naturally Occurring and Vaccine-Induced Antibodies Against Tat on the Course of the Disease. Vaccines 2019, 7, 99. [CrossRef]

91. Ensoli, F.; Cafaro, A.; Casabianca, A.; Tripiciano, A.; Bellino, S.; Longo, O.; Francavilla, V.; Picconi, O.; Sgadari, C.; Moretti, S.; et al. HIV-1 Tat immunization restores immune homeostasis and attacks the HAART-resistant blood HIV DNA: Results of a randomized phase II exploratory clinical trial. Retrovirology 2015, 12, 33. [CrossRef] [PubMed]

92. Ensoli, B.; Nchabeleng, M.; Ensoli, F.; Tripiciano, A.; Bellino, S.; Picconi, O.; Sgadari, C.; Longo, O.; Tavoschi, L.; Joffe, D.; et al. HIV-Tat immunization induces cross-clade neutralizing antibodies and CD4 [+] T cell increases in antiretroviral-treated South African volunteers: A randomized phase II clinical trial. Retrovirology 2016, 13, 34. [CrossRef] [PubMed]

93. Sgadari, C.; Monini, P.; Tripiciano, A.; Picconi, O.; Casabianca, A.; Orlandi, C.; Moretti, S.; Francavilla, V.; Arancio, A.; Paniccia, G.; et al. Continued Decay of HIV Proviral DNA Upon Vaccination With HIV-1 Tat of Subjects on Long-Term ART: An 8-Year Follow-Up Study. Front. Immunol. 2019, 10, 233. [CrossRef] [PubMed]

94. Fisher, A.G.; Feinberg, M.B.; Joseph, S.F.; Harper, M.E.; Marselle, L.M.; Reyes, G.; Gonda, M.A.; Aldovini, A.; Debouk, C.; Gallo, R.C.; et al. The trans-activator gene of HTLV-III is essential for virus replication. Nature 1986, 320, 367-371. [CrossRef]

95. Pierleoni, R.; Menotta, M.; Antonelli, A.; Sfara, C.; Serafini, G.; Dominici, S.; Laguardia, M.E.; Salis, A.; Damonte, G.; Banci, L.; et al. Effect of the redox state on HIV-1 tat protein multimerization and cell internalization and trafficking. Mol. Cell Biochem. 2010, 345, 105-118. [CrossRef]

96. Rossi, C.; Balboni, P.G.; Betti, M.; Marconi, P.C.; Bozzini, R.; Grossi, M.P.; Barbanti-Brodano, G.; Caputo, A. Inhibition of HIV-1 replication by a Tat transdominant negative mutant in human peripheral blood lymphocytes from healthy donors and HIV-1-infected patients. Gene Ther. 1997, 4, 1261-1269. [CrossRef]

97. Monini, P.; Cafaro, A.; Srivastava, I.K.; Moretti, S.; Sharma, V.A.; Andreini, C.; Chiozzini, C.; Ferrantelli, F.; Cossut, M.R.P.; Tripiciano, A.; et al. HIV-1 Tat Promotes Integrin-Mediated HIV Transmission to Dendritic Cells by Binding Env Spikes and Competes Neutralization by Anti-HIV Abs. PLoS ONE 2012, 7, e48781. [CrossRef]

98. Shi, F.; Sottile, J. Caveolin-1-dependent beta1 integrin endocytosis is a critical regulator of fibronectin turnover. J. Cell Sci. 2008, 121, 2360-2371. [CrossRef] 
99. Dominguez, C.; Boelens, R.; Bonvin, A.M. HADDOCK: A protein-protein docking approach based on biochemical or biophysical information. J. Am. Chem. Soc. 2003, 125, 1731-1737. [CrossRef]

100. Webb, B.; Sali, A. Comparative Protein Structure Modeling Using MODELLER. Curr. Protoc. Bioinform. 2016, 54, 1-37. [CrossRef]

101. Péloponèse, J.M.; Collette, Y.; Grégoire, C.; Bailly, C.; Campèse, D.; Meurs, E.F.; Olive, D.; Loret, E.P. Full peptide synthesis, purification, and characterization of six Tat variants. Differences observed between HIV-1 isolates from Africa and other continents. J. Biol. Chem. 1999, 274, 11473-11478. [CrossRef] [PubMed]

102. Gregoire, C.; Péloponèse, J.M.; Esquieu, D.; Opi, S.; Campbell, G.; Solomiac, M.; Lebrun, E.; Lebreton, J.; Loret, E.P. Homonuclear (1)H-NMR assignment and structural characterization of human immunodeficiency virus type 1 Tat Mal protein. Biopolymers 2001, 62, 324-335. [CrossRef] [PubMed]

103. Hubbard, S.J.; Thornton, J.M. NACCESS Computer Program; Department of Biochemistry and Molecular Biology, University College London: London, UK, 1993. 